Article

\title{
Applying the ICAT Sustainable Development Methodology to Assess the Impacts of Promoting a Greater Sustainability of the Charcoal Value Chain in Mozambique
}

\author{
Sá Nogueira Lisboa * ${ }^{\mathbb{D}}$, Rosta Mate, Américo Manjate and Almeida Sitoe \\ Faculty of Agronomy and Forest Engineering, Eduardo Mondlane University, Maputo 1100, Mozambique; \\ rostamate@gmail.com (R.M.); rildomanjate@yahoo.com.br (A.M.); almeidasitoe@gmail.com (A.S.) \\ * Correspondence: sanogueiralisboa@gmail.com; Tel.: +258-849-697-177
}

Received: 3 October 2020; Accepted: 26 October 2020; Published: 11 December 2020

check for updates

\begin{abstract}
This study assesses greenhouse gas emission (GHG) reductions and sustainable development impacts connected to the nationally appropriate mitigation action (NAMA) on sustainable charcoal production in Mozambique. The analysis covers the results of the ex-ante assessment of the NAMA potential contribution to the achievement of Mozambique's Nationally Determined Contribution (NDC) target. The expected impacts show that the proposed actions tied to NAMA (e.g., introducing improved kilns, sustainable forest management, briquetting of charcoal waste and torrefaction) can cumulatively lead to emission reductions amounting to $314,521 \pm 45,138 \mathrm{t} \mathrm{CO}_{2}$-eq (119\% reduction) by 2025 , and $442,706 \pm 26,766 \mathrm{t} \mathrm{CO}_{2}$-eq (113\% reduction) by 2030 at the national level, compared to a business as usual scenario. This shifting represents a transformation of the charcoal sector from a net source of emissions to net carbon sequestrating. The analysis also identifies a wide range of sustainable development cobenefits, including increased income, improved gender equity, job creation ( $23 \%$ increase by 2025 , and $15 \%$ decrease by 2030 ), and increased revenue (USD 825,000 by 2025 , and USD 1.6 million by 2030). The assessment process concluded that unless robust data collection, processing, and sharing is put in place, a full assessment of all direct and indirect environmental, social, and economic impacts cannot be comprehensively reported. Finally, we highlight the lessons learned and specific barriers for a robust monitoring, reporting, and verification (MRV) of the given policy under the current MRV set up and available capacities.
\end{abstract}

Keywords: charcoal value chain; sustainable development goal; national determine action; enhanced transparency framework; greenhouse gas emission; charcoal production; biomass energy

\section{Introduction}

With the adoption of the Paris Agreement in 2015, the United Nations Framework Convention on Climate Change (UNFCCC) and the Parties to the Convention have agreed on a common framework to reach the objective to limit the increase in global average temperature at well below $2{ }^{\circ} \mathrm{C}$, relative to preindustrial levels, and pursue efforts to limit warming to $1.5^{\circ} \mathrm{C}$. The intended vehicle for each country to achieve these objectives is detailed within their Nationally Determined Contributions (NDCs), defining priorities for mitigation and adaptation actions, achieving national emission reduction contributions, and enhancing resilience and adapting to the impacts of climate change [1]. Mozambique's NDC operational plan includes a specific section on a Nationally Appropriate Mitigation Action (NAMA) for Promoting Sustainability of the Charcoal Value Chain in Mozambique. Transparency of mitigation efforts, including the NAMA, is paramount to monitor the NDC implementation, enhance confidence and trust amongst countries, and promote effective implementation of the Paris Agreement. 
Like most developing countries, in Mozambique around 80-82\% of the population relies on traditional biomass (firewood and charcoal) as their primary energy source [2]. The demand for conventional biomass has been increasing in Mozambique due to population growth and rising poverty [3]. With a continuous population increase, particularly of the urban population, demand for cheap energy sources such as biomass will increase. The consumption pattern differs between rural and urban areas, and charcoal is dominated mainly in periurban and urban areas $[4,5]$. The charcoal sector is currently informal and mostly unregulated. Moreover, charcoal is produced using inefficient, traditional earth kilns. This has resulted in a high level of deforestation and forest degradation countrywide [6,7]. Charcoal producers do not have access to knowledge or technology for sustainable charcoal production, and there is no incentive or regulation to produce charcoal efficiently $[8,9]$. Modern energy carriers that are efficient such as gas and electricity are limited by the high initial investment costs for stoves and electricity connection and its poor distribution network $[5,10]$.

The government of Mozambique has developed a strategy to make use of biomass energy resources more efficiently and sustainably to reduce the biomass extraction associated with deforestation and forest degradation while increasing the consumption of clean fuel and thus lowering greenhouse gas (GHG) emissions. The analysis includes assessing potential GHG impacts and exploring a wide range of other selected sustainable development indicators. The assessment of the possible effects of policies and actions is also considered a key step towards developing effective, sustainable development strategies. It will, therefore, also contribute to the assessment and improvement of the NDC. The specific objective of the analysis is to:

a. Identify other impact categories of the NAMA Charcoal and establish how to mitigate negative impacts while strengthening positive ones;

b. Conduct an ex-ante assessment of policy Charcoal NAMA, including the development of a baseline, policy scenarios, and estimation of sustainable development impacts;

c. Identify barriers and gaps in monitoring and reporting of indicators and parameters for the policy NAMA Charcoal and identify ways to overcome these barriers to enhance the transparency of the framework at the national level.

\section{Background}

To contribute to the achievement of Strategy for the Conservation and Sustainable Use of Biomass Energy objectives, the Ministry of Energy through the National Energy Fund (FUNAE) - the implementing entity—and with the collaboration of development partners, formulated the NAMA Promoting Sustainability of the Charcoal Value Chain in Mozambique (hereafter named NAMA). In the NDC of Mozambique, approved in December 2018, the NAMA actions and measures are also included to promote the alignment of national legal documents and facilitate access to financial and technical resources. The NAMA was designed in 2014 and proposed with a timeframe up to 2020, and was intended to be implemented at the sub-national and national scale. However, NAMA was never implemented, so in this study, the timeframe was scaled up to 2025 and 2030 and analyzed at the pilot area (subnational scale) and the national level.

NAMA's ultimate goal is to reduce the volume of wood used to produce the charcoal consumed in Maputo by at least $25 \%$ by 2030 and consequently reduce the GHG emissions resulting from the charcoal produced and consumed in Maputo. The following objectives are also aligned with the overall goal: (1) Reduced deforestation rate due to lower demand for fuelwood because of improved and more efficient kilns, sustainable forest management practices, and use of improved stoves; (2) reduced forest degradation as a result of the adoption of sustainable forest management practices; (3) maintained and secured biodiversity conservation in forest areas under sustainable forest management practices; and finally, (4) jobs creation, alternative income, and improved income streams for charcoal producers engaged in the NAMA implementation project.

The government considered various actions to achieve the defined NAMA's objectives, such as (1) Introduction of new technologies in the charcoal production (improved kilns, sustainable forest 
management practices, training of producers and technicians); (2) identification and introduction of a viable model of improved and efficiently produced charcoal; (3) formalization of the charcoal sector or biomass energy sector and definition of a new charcoal business model; (4) identification of appropriate mechanisms for distribution or sale of improved stoves, charcoal training in the use of new technologies; and (5) training of government technicians involved in control and management of biomass resources, institutional capacity building, education, and awareness campaigns.

Assessing the defined actions in the current NAMA document could also incorporate other charcoal-related actions currently not covered by the NAMA, resulting in additional GHG mitigation and sustainable development impacts. For instance, the feasibility study on climate financing for a Sustainable Charcoal Production Chain [11] assessed six business models, namely: (1) briquetting charcoal residues; (2) introducing modern kilns and sustainable forest management; (3) private sector plantations with native trees; (4) forest plantation residues; (5) charcoal from other sources; and (6) torrefaction by the private sector. With the NAMA implementation, around 200 traditional kilns will be replaced by improved and more efficient kilns in the production site, and the NAMA also envisions the distribution of 100,000 improved stoves in the consumption site. The policy is aligned with sustainable development goal (SDG) 1 (No Poverty), SDG 2 (Zero Hunger), SDG 3 (Good Health and Well-Being), SDG 6 (Clean Water and Sanitation), SDG 7 (Affordable and Clean Energy), SDG 8 (Decent Work and Economic Growth), SDG 9 (Industry, Innovation, and Infra-structure), SDG 10 (Reduced Inequalities), SDG 11 (Sustainable Cities and Communities), SDG 12 (Responsible Consumption and Production), SDG 13 (Climate Action), SDG 15 (Life on Land), SDG 17 (Peace, Justice and Strong Institutions), and indirectly SDG 4 (Quality Education) through the investment of income in education [12].

\section{Materials and Methods}

\subsection{Methodological Approach}

The analysis applied the ICAT Sustainable Development Methodology to evaluate the NAMA's expected impacts to identify the contribution that it will have in the achievement of Mozambique's Nationally Determined Contribution Objectives 2020-2030 as well as to the Sustainable Development Goals. Therefore, as the NAMA is not yet implemented, its impacts are assessed ex-ante. In total, 3 leading technologies/approaches have been identified by the NAMA and used in the GHG and sustainable development impact assessment [11]:

1. Briquetting charcoal residues: The current production process leaves a significant volume of small pieces and charcoal dust in the field. A rough estimate would suggest a loss of $200 \mathrm{~kg}$ material per kiln production, which can be used for briquette.

2. Modern kilns and sustainable forest management: Efficient and modern kilns allow for more efficient charcoal production: a brick kiln has a 3:1 (wood/charcoal) ratio instead of 7:1 by the current earth kilns. Producers experience forest degradation as a limitation to their production, and the introduction of efficient kilns should, therefore, be combined with sustainable forest management (SFM).

3. Torrefaction by the private sector: torrefaction can be a commercially viable option in regions with (a) a high level of charcoal production with producers that already produce the maximum amount allowed by their licenses, and (b) lower levels of organizational capacity and thus fewer opportunities for the above-mentioned projects.

The approach used in this study consisted of field observation and literature review of relevant publications such as technical reports and many peer-reviewed journals on charcoal value chains, which were used to support the assessment. Assumptions or expert judgment was required in cases where information is not available to make a reasonable assumption about a parameter's value. The analysis also identified policies and strategies related to charcoal production in Mozambique, 
focusing on the national NAMA document, sustainable charcoal production feasibility study [11], the National Climate Change Adaptation and Mitigation Strategy, and Mozambique's NDC document. For data collection, the analysis used a socio-ecological approach, including questionnaires with charcoal producers $(n=68)$, charcoal transporters $(n=21)$, local energy institutions $(n=18)$, charcoal sellers ( $n=62)$ as well as forest surveys (Supplementary Materials). The questionnaire to charcoal suppliers contained questions that catch a big picture of the whole process of charcoal production in the pilot area. The fieldwork took place in December 2018 and February 2019. The assessment was performed in 4 districts targeted by this study (Massingir, Chicualacuala, Guija, and Mabalane districts) in Gaza province (Figure 1). The NAMA has selected Southern Mozambique as the pilot area for mitigation projects where the NAMA should be implemented. The selected 3 districts are historic charcoal producers districts and where charcoal-driven forest degradation is very high [13].
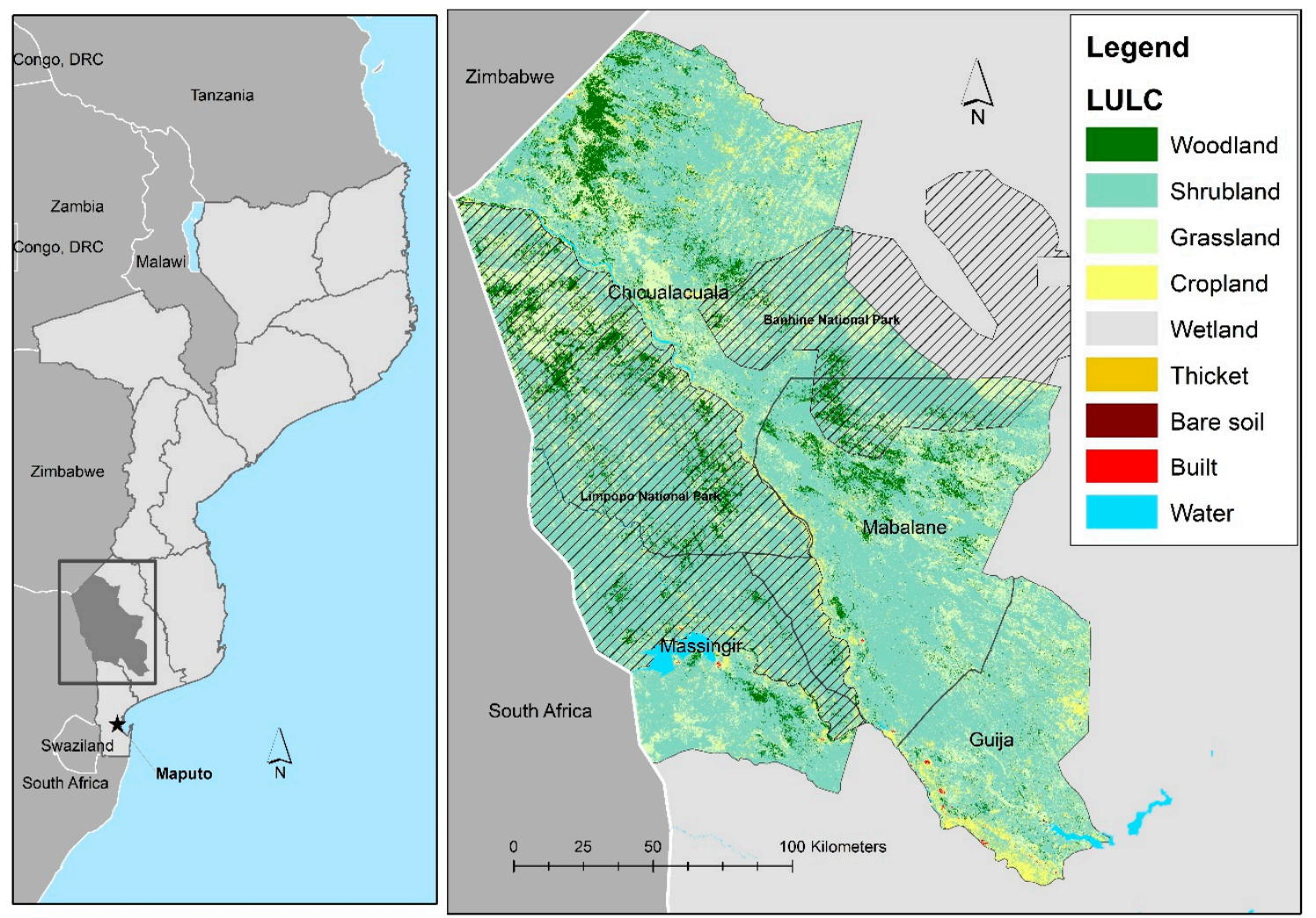

Figure 1. Land use and land cover map of the study area (Chicualacuala, Massingir, Mabalane, and Guija districts), Gaza province, Southern Mozambique.

All estimation and assumptions were made for the energy and forest sectors, meaning that the analysis was performed for the pilot area (subnational level) and scaled up at the national level.

\subsection{Identification and Selection of Impact Categories of the NAMA Charcoal}

We assessed each NAMA technology such as improved kilns and sustainable forest management, briquetting of charcoal waste, and torrefaction from forest plantation in 3 dimensions: environmental, economic and social, and impact categories (air, soil, land, forest, and biodiversity, jobs, energy, health, etc.) were identified and assessed within each dimension, and indicators for each impact category were selected (Supplementary Materials). The identification, prioritization, and categorization of impacts we made through available literature and policy review. Additionally, we consulted stakeholders through workshops who have been working actively in the energy sector, including stakeholders directly involved in the charcoal sector at the national level. The local level was consulted using semistructured interviews and focus group discussion in the selected districts. We assessed each specific impact based 
on its likelihood of occurring, its expected magnitude (major, moderate, or minor), and the change (positive or negative). In the end, we selected the relevant impact to be assessed based on significance, relevance, and comprehensiveness. An initial matrix was developed, including the identified specific impacts within each impact category.

\subsection{Impact Assessment of Charcoal NAMA and Scenario Narratives}

The NAMA's impact assessment was done following the ICAT Sustainable Development Guidance [14], allowing for both a qualitative and quantitative impact assessment. We constrained most of the social and economic impact indicators by the availability of relevant and reliable data. Hence its quantification was not feasible because of a lack of data; then, its impact we assessed using a qualitative approach. For all scenarios, we established a baseline and estimated the scenarios based on future expectations. Coefficients were generated and used to predict the parameters variation for the period of assessment 2020-2030 for the modeling exercise, based on available data (Supplementary Materials). We considered 2 distinct periods in the time horizon covered by the assessment, the first 2020-2025 and the second 2026-2030, estimated at the subnational and national levels for the climate change impact category (Table 1) and at the national level for social and economic impact categories (Table 2). By 2020, we expected that the project will have already been implemented, and by 2030 fully operational. However, as stated in the NDC, its implementation is contingent upon international support availability, which is also the case to enable full implementation of the NAMA within the timeline described. We estimated the policy impact by subtracting baseline values from policy scenario values. The scenario description and assumption at the pilot area and national scale of climate change impact categories are described in Table 1, while the scenario natives of social and economic impact categories are in Table 2.

Table 1. Scenario narratives of climate change impact category for the subnational (pilot area) and the national scale of the nationally appropriate mitigation action (NAMA)'s sustainable development impacts.

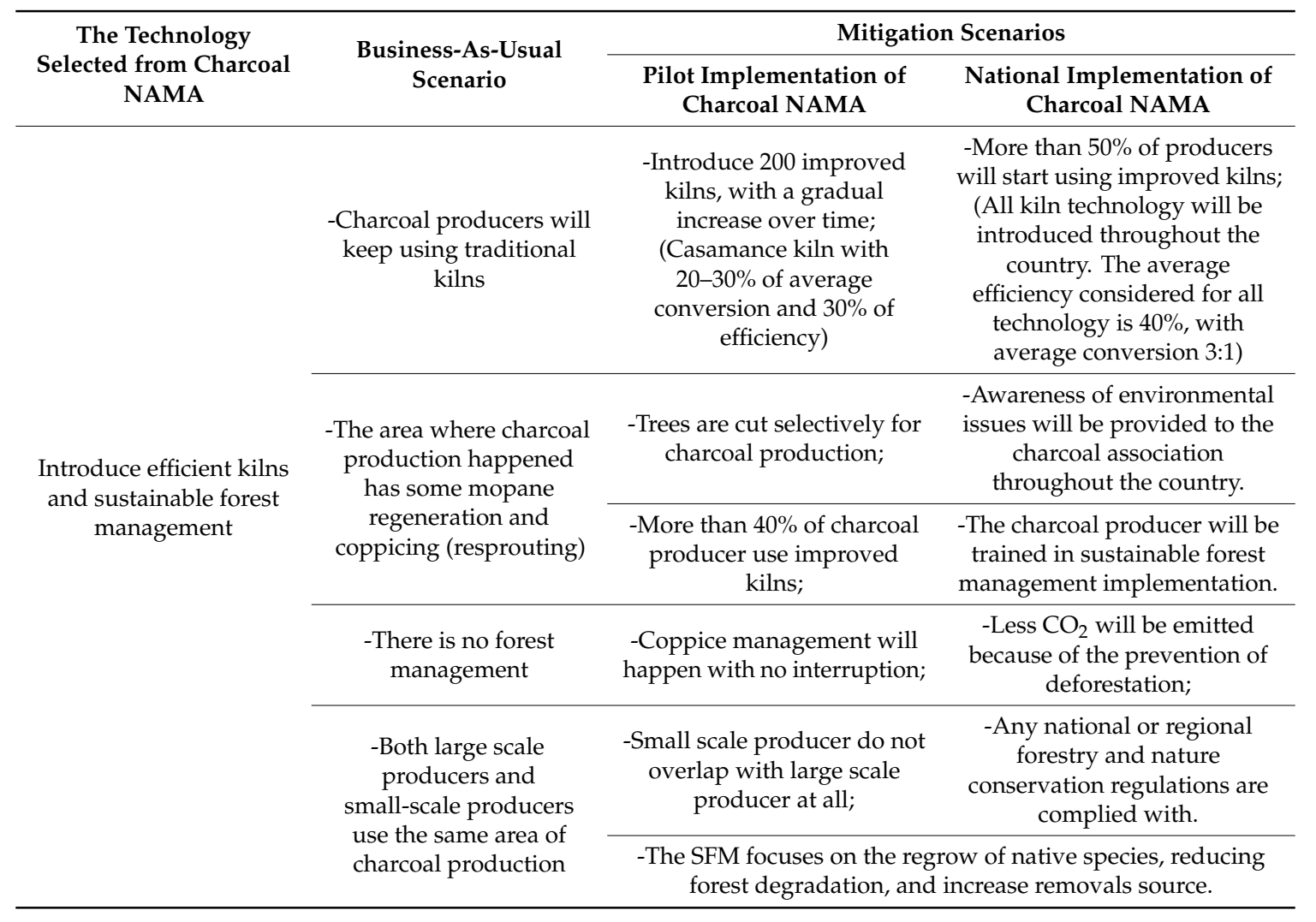


Table 1. Cont.

\begin{tabular}{|c|c|c|c|}
\hline \multirow{2}{*}{$\begin{array}{c}\text { The Technology } \\
\text { Selected from Charcoal } \\
\text { NAMA }\end{array}$} & \multirow{2}{*}{$\begin{array}{l}\text { Business-As-Usual } \\
\text { Scenario }\end{array}$} & \multicolumn{2}{|c|}{ Mitigation Scenarios } \\
\hline & & $\begin{array}{l}\text { Pilot Implementation of } \\
\text { Charcoal NAMA }\end{array}$ & $\begin{array}{c}\text { National Implementation of } \\
\text { Charcoal NAMA }\end{array}$ \\
\hline \multirow{2}{*}{$\begin{array}{l}\text { Briquetting charcoal } \\
\text { waste materials }\end{array}$} & \multirow{2}{*}{$\begin{array}{l}\text {-Charcoal is produced } \\
\text { using traditional kilns } \\
\text { with low efficiency, and } \\
100 \% \text { of the charcoal } \\
\text { waste powder and small } \\
\text { fragments remain } \\
\text { non-utilized }\end{array}$} & $\begin{array}{l}\text {-Fewer trees will be logged, } \\
\text { and } \mathrm{CO}_{2} \text { will be emitted } \\
\text { while producing the same } \\
\text { amount of charcoal; }\end{array}$ & $\begin{array}{l}\text {-Fewer trees will be logged, } \\
\text { and } \mathrm{CO}_{2} \text { will be emitted, } \\
\text { while producing the same } \\
\text { amount of charcoal }\end{array}$ \\
\hline & & $\begin{array}{l}\text {-Briquetting will reduce in } \\
25 \% \text { of GHG emissions from } \\
\text { charcoal production. }\end{array}$ & $\begin{array}{l}\text {-Briquetting will reduce in 20\% } \\
\text { of GHG emission from } \\
\text { charcoal production }\end{array}$ \\
\hline $\begin{array}{l}\text { Torrefaction by the } \\
\text { private sector } \\
\text { (forest plantation) }\end{array}$ & $\begin{array}{l}\text { There is no and will be } \\
\text { implemented any } \\
\text { torrefaction project }\end{array}$ & $\begin{array}{l}\text {-At least } 10 \text { ha of woodlot } \\
\text { plantation will be } \\
\text { established for torrefaction } \\
\text { in the pilot area. The pilot } \\
\text { area is semi-arid and needs } \\
\text { drought-tolerant species. }\end{array}$ & $\begin{array}{l}\text {-Woodlot plantation for } \\
\text { torrefaction will increase by } \\
30 \% \text { throughout the country } \\
\text { under the MozFIP project }\end{array}$ \\
\hline $\begin{array}{l}\text { Cumulative scenario } \\
\text { (sum all technology) }\end{array}$ & $\begin{array}{l}\text { We are considering all } \\
\text { BAU assumptions. }\end{array}$ & $\begin{array}{l}\text {-We are considering all pilot } \\
\text { NAMA implementation } \\
\text { assumptions. }\end{array}$ & $\begin{array}{l}\text {-We are considering national } \\
\text { NAMA implementation } \\
\text { assumptions. }\end{array}$ \\
\hline
\end{tabular}

We generated the emission scenario of transportation only for transport in the pilot area. There is a lack of data and proxies in the energy sector (fuel consumption of charcoal transportation) for emission estimation at the national scale. We believe that the amount of fuel for charcoal transportation will increase with the Charcoal NAMA implementation due to the increased amount of deliveries. 
Table 2. Scenario narratives of quantitative assessment for social and economic dimension of the NAMA's sustainable development impacts.

\begin{tabular}{|c|c|c|c|c|c|}
\hline Impact Categories & Specific Impacts Identified & Indicator & Baseline (BAU)—National & Source & NAMA Scenario 2020-2030 \\
\hline \multicolumn{6}{|c|}{ ENVIRONMENTAL DIMENSION } \\
\hline $\begin{array}{l}\text { Climate Change } \\
\text { Mitigation }\end{array}$ & \multicolumn{5}{|c|}{ Quantified separately (see Table 1) } \\
\hline \multirow{2}{*}{$\begin{array}{c}\text { The energy } \\
\text { produced in a } \\
\text { sustainable manner }\end{array}$} & \multirow{2}{*}{$\begin{array}{l}\text { Increase in complementary } \\
\text { biomass and charcoal waste } \\
\text { used, which will increase } \\
\text { access to charcoal and other } \\
\text { energy carriers (briquettes, } \\
\text { torrefied material) produced } \\
\text { in a sustainable way }\end{array}$} & $\begin{array}{l}\text { Number of licensed charcoal } \\
\text { producers engaged in } \\
\text { charcoal efficiently produced } \\
\text { and environmentally friendly }\end{array}$ & $\begin{array}{c}-4 \% \text { of licensed operators } \\
-100 \% \text { of charcoal produced } \\
\text { unsustainably; }\end{array}$ & {$[12,15-17]$} & $\begin{array}{l}\text {-The NAMA is expected to contribute } \\
\text { to the increase of sustainable charcoal } \\
\text { made by } 2 \% \text { per year. At least } 20 \% \text { of } \\
\text { produced charcoal sustainable } \\
\text { by } 2025\end{array}$ \\
\hline & & $\begin{array}{c}\text { Number of charcoal } \\
\text { consumers using sustainably } \\
\text { produced charcoal }\end{array}$ & $\begin{array}{l}-28 \% \text { population with access to clean } \\
\text { energy (electricity, gas) } \\
-80 \% \text { of urban and periurban areas are } \\
\text { dependent on charcoal and wood for } \\
\text { energy production. At least } 60 \% \text { can be } \\
\text { assumed as a charcoal } \\
\text { dependent population. }\end{array}$ & {$[2,5,15]$} & $\begin{array}{l}\text {-An increase of } 25 \% \text { per year of } \\
\text { people consuming sustainable } \\
\text { charcoal in urban and peri-urban } \\
\text { areas of the major cities Maputo, } \\
\text { Matola, and (if National level, } \\
\text { Nampula, Zambézia) is expected. }\end{array}$ \\
\hline \multicolumn{6}{|c|}{ SOCIAL DIMENSION } \\
\hline \multirow[t]{2}{*}{ Education } & $\begin{array}{l}\text { Improved access to education } \\
\text { for local children }\end{array}$ & $\begin{array}{l}\text { Number of children enrolled } \\
\text { in school }\end{array}$ & $\begin{array}{l}\text {-Assumptions of the scenario provided } \\
\text { by the Plano Estratégico de Educação } \\
\text { (2012-2016) in which the entry }(10 \%) \\
\text { and transition rates between different } \\
\text { education levels are expected to be } \\
\text { maintained. The rate of school } \\
\text { dropouts ( } 31.4 \%) \text { and class repetition } \\
(28.2 \%) \text {. Transition between grades } 7 \text { to } \\
8(80 \%), 10 \text { to } 11(60-70 \%) \text {. School entry } \\
\text { and transition rates will be maintained } \\
\text { between different levels of education. }\end{array}$ & {$[8,18]$} & $\begin{array}{c}\text {-An increase in income will allow } \\
\text { coverage of education expenses by } \\
\text { charcoal stakeholders involved in the } \\
\text { value chain. }\end{array}$ \\
\hline & $\begin{array}{l}\text { Improved ability to produce } \\
\text { charcoal sustainably by } \\
\text { capacity, skills, and } \\
\text { knowledge development }\end{array}$ & $\begin{array}{l}\text { Number of workers in the } \\
\text { charcoal value chain using } \\
\text { more efficient and sustainable } \\
\text { charcoal production } \\
\text { technologies and forest } \\
\text { management practices }\end{array}$ & $\begin{array}{l}\text { Previous projects report that awareness } \\
\text { campaigns for sustainable charcoal } \\
\text { production have been conducted. } \\
\text { However, no records are available. }\end{array}$ & {$[8,9,19]$} & $\begin{array}{l}\text { The NAMA project includes } \\
\text { awareness and training as activities. }\end{array}$ \\
\hline
\end{tabular}


Table 2. Cont.

\begin{tabular}{|c|c|c|c|c|c|}
\hline Impact Categories & Specific Impacts Identified & Indicator & Baseline (BAU)-National & Source & NAMA Scenario 2020-2030 \\
\hline Gender equity & $\begin{array}{l}\text { Increased gender equality } \\
\text { promotion and women } \\
\text { empowerment by created } \\
\text { charcoal associations }\end{array}$ & $\begin{array}{c}\% \text { of women involved in } \\
\text { activities in the charcoal value } \\
\text { chain }\end{array}$ & $\begin{array}{l}\text { The percentage of women in charcoal } \\
\text { production at the national level } \\
\text { historically does not exceed } 10 \% .\end{array}$ & $\begin{array}{c}\text { Fieldwork } \\
\text { estimates, } \\
\text { De Koning et al. } \\
{[11]}\end{array}$ & $\begin{array}{c}\text { The charcoal producers' organization } \\
\text { in associations will allow integration } \\
\text { of women and other groups in the } \\
\text { value chain. NAMA has activities of } \\
\text { forest management and stoves that } \\
\text { might create opportunities. }\end{array}$ \\
\hline \multicolumn{6}{|c|}{ ECONOMIC DIMENSION } \\
\hline Labor & $\begin{array}{l}\text { Increased number of } \\
\text { employed people in the } \\
\text { charcoal value chain } \\
\text { (green jobs) }\end{array}$ & $\begin{array}{l}\text { Number of people working in } \\
\text { the sector }\end{array}$ & 87,000 people employed & {$[20,21]$} & $\begin{array}{c}\text { Increased to } 100,000 \text { workers by } 2025 \\
\text { and } 150,000 \text { by } 2030 \text { (average of } \\
15 \text { years) }\end{array}$ \\
\hline Income & $\begin{array}{l}\text { Local communities will } \\
\text { receive } 20 \% \text { of the shared } \\
\text { revenue of charcoal licensing. }\end{array}$ & $\begin{array}{c}\text { Amount of revenues from } \\
\text { charcoal's licensing delivered } \\
\text { to the community }\end{array}$ & $\begin{array}{l}\text { The government accesses only about } \\
4 \% \text { of the sector's revenue through } \\
\text { charcoal licensing. }\end{array}$ & [21] & $\begin{array}{l}\text { District Service for Economic } \\
\text { Activities (SDAE) could increase its } \\
\text { revenue by about } 50.1 \text { million Mt in } \\
2025 \text { and } 100.7 \text { million Mt by } 2030 \text {, } \\
\text { With } 10.0 \text { million MZN per year } \\
\text { going to the communities in } 2025 \text { and } \\
20.1 \text { million MZN per year in } 2030 \\
\text { as their } 20 \% \text { shares of license revenue. }\end{array}$ \\
\hline Revenue & $\begin{array}{l}\text { Increase in total revenue in } \\
\text { the sector }(\% \mathrm{GDP})\end{array}$ & $\begin{array}{l}\% \text { change in the forest sector } \\
\text { revenue as a result of NAMA }\end{array}$ & $\begin{array}{l}\text { Forest sector GDP varies between } 4 \text { to } \\
11 \% \text {, increased illegal logging and lack } \\
\text { of recording limits the contribution }\end{array}$ & {$[20,21]$} & $\begin{array}{l}\text { Improvement of registration and } \\
\text { control of licensed charcoal and } \\
\text { produced efficiently, is expected an } \\
\text { increase in forest sector revenue by } \\
5 \% \text { a year, from the NAMA } \\
\text { implementation }\end{array}$ \\
\hline
\end{tabular}




\subsection{Activity Data for Baseline Scenario Development}

We collected the activity data from social and economic indicators in the field, and most of them from the literature were also collected (see the source in Table 2). We performed the baseline emission scenario of charcoal production using forest degradation areas due to charcoal production. The kilns in Mabalane district were mapped using very high-resolution images, where accurate data exists from 2008 to 2018, and forest degradation rate was computed [7]. The rate of forest degradation from Mabalane [6,7,13] and the national scale [22] was used to extrapolate the activity data to other districts (Chicualacuala, Massingir, and Guija) in the pilot area and at the national level, respectively. According to the provincial government, charcoal production in Massingir and Guija has currently been banned (local government, personal communication). The activity data and all assumptions to these districts were more conservative compared to other districts. We performed the activity data of Chicualacuala, Massingir, and Guija from a map of African Land Cover 2016 (Sentinel 2, $20 \mathrm{~m}$ spatial resolution) and Normalized Difference Vegetation Index (NDVI) map from Google Earth Engine extracted to the study area. The GPS coordinate of the kilns was collected in the field to validate the NDVI map of charcoal production. The emission from forest degradation or deforestation driven by charcoal production in the study area was computed from 2008 to 2018 and then extrapolated to 2025 and 2030, assuming that the forest degradation area will decrease by $245.65 \mathrm{ha} \mathrm{yr}^{-1}$ if charcoal production happens as business-as-usual (e.g., mopane species will become scarce because of high intensity of charcoal extraction). The emissions from 2015 to 2025 were estimated by multiplying the activity data by the emission factor of charcoal production computed from forest survey (Supplementary Materials).

\subsection{Estimation of a Baseline of Emission Reduction Potential of Identified Mitigation Technologies in the Charcoal NAMA}

The potential reduction of GHG emissions from charcoal production from different identified mitigation measures was estimated using combined methods under Clean Development Mechanism (CDM) the following UNFCCC registered methodologies developed for the charcoal production sector. (i) AMS-III.BG [23]: emission reduction through sustainable charcoal production and consumption; (ii) AMS-III.K [24]: avoidance of methane release from charcoal production; and (iii) ACM0021 [25]: reduction of emissions from charcoal production by improved kiln design and/or abatement of methane.

We identified the mitigation measures selected in this study from the charcoal NAMA project, which is more likely to be implemented. That meant that we estimated the potential emission reductions only for (i) briquetting of charcoal waste and agricultural waste, (ii) introducing efficient kilns and sustainable forest management of charcoal production, and (iii) torrefaction by the private sector (and replanting). According to De Koning et al. [11], no methodology fully applicable accounts for avoided emissions due to the implementation of improved kilns combined with forest management. Therefore, we addressed the scenario of avoided emissions from introducing efficient kilns and sustainable forest management by combining approaches from CDM methodology [24-26], and 2006 IPCC Guidelines [26] (Supplementary Materials for the potential of emission reduction equations).

\subsection{Evaluate and Validate the Impact Categories and Scenarios}

The identified impacts and scenarios were validated by key stakeholders in a consultation workshop in Maputo in April 2019. A questionnaire was applied to gather charcoal producers' responses, drivers of charcoal transportation, local institutions, and local traders to validate the impact categories from social and economic dimensions. The questionnaire at the district level and consultation workshops city levels at consumption site (Maputo and Matola) were conducted to collect stakeholders' perceptions and validate relevant impacts from different charcoal value chain stages, namely; production, transportation, marketing, and consumption. Following the identification of the relevant impact categories, verification was made of the categories significantly affected by the NAMA 
implementation. We used the interview result at the district level to make the last judgment of each selected impact's significance and magnitude.

\section{Results}

\subsection{Qualitative Assessment of the Identified Impact of Charcoal NAMA}

Table 3 below presents the qualitative assessment results of the specific impacts and provides a classification of impact dimension (environmental, economic, and social) and contribution to SDGs. The table also includes data sources and justification for the exclusion of specific impacts from the quantitative assessment. Data limitations that would allow the quantification of impacts at this stage are the primary reason for excluding these impacts from the quantitative assessment. Another issue that hinders quantification is the lack of available methods to establish the attribution of impacts to the NAMA activities from impacts that could result from various measures, such as reduced air pollution and reduction on economic costs of health losses. 
Table 3. Reporting the qualitative impact assessment of Charcoal NAMA and link to sustainable development goals (SDGs).

\begin{tabular}{|c|c|c|c|c|c|c|c|c|c|c|c|c|c|}
\hline 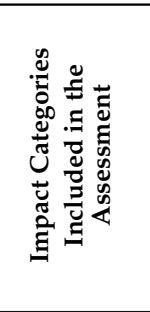 & 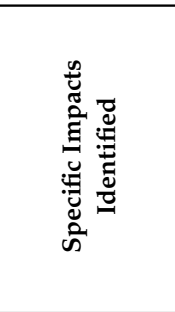 & 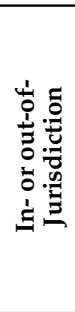 & 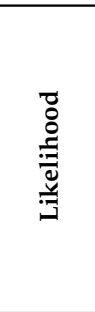 & 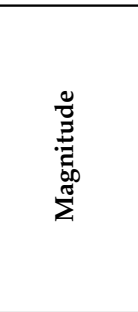 & 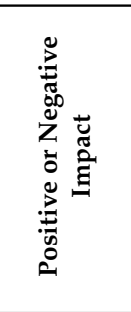 & 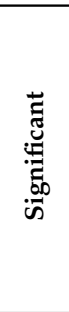 & 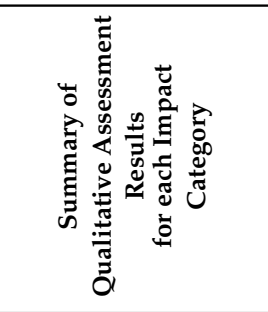 & 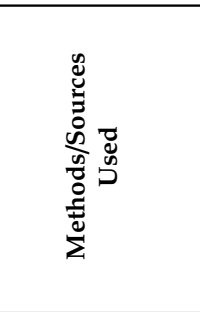 & 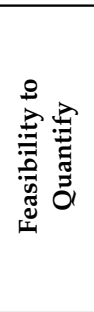 & 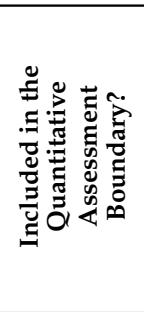 & 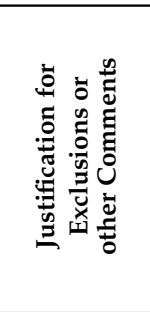 & 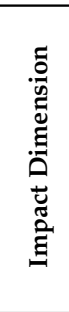 & 识 \\
\hline \multirow[t]{2}{*}{$\begin{array}{l}\text { Climate } \\
\text { Change } \\
\text { Mitigation }\end{array}$} & $\begin{array}{l}\text { Reduction of } \\
\text { GHG } \\
\text { emission } \\
\text { from the } \\
\text { introduction } \\
\text { of new } \\
\text { technologies } \\
\text { and practices }\end{array}$ & \multirow[t]{2}{*}{ Both } & $\begin{array}{c}\text { Very } \\
\text { likely }\end{array}$ & \multirow[t]{2}{*}{ Moderate } & Positive & Yes & $\begin{array}{l}\text { The significant } \\
\text { positive impact of } \\
\text { charcoal production } \\
\text { technology. While } \\
\text { negative impacts do } \\
\text { exist, they are } \\
\text { insignificant }\end{array}$ & $\begin{array}{c}\text { Stakeholder } \\
\text { consultation, } \\
\text { field studies, } \\
\text { Clean } \\
\text { Development } \\
\text { Mechanism } \\
\text { methodologies } \\
\text { [23-25], and } \\
\text { 2006 IPCC } \\
\text { [26] }\end{array}$ & Yes & Yes & Included & & \\
\hline & $\begin{array}{l}\text { Increased } \\
\text { emissions } \\
\text { from } \\
\text { increase in } \\
\text { transport } \\
\text { need }\end{array}$ & & Likely & & Negative & No & $\begin{array}{c}\text { Emission from } \\
\text { transport, product } \\
\text { distribution might } \\
\text { be increased, } \\
\text { however not } \\
\text { significant } \\
\end{array}$ & $\begin{array}{c}\text { Field } \\
\text { estimates } \\
\text { and } 2006 \\
\text { IPCC [26] }\end{array}$ & Yes & Yes & $\begin{array}{l}\text { Included, } \\
\text { but no } \\
\text { reliable } \\
\text { data }\end{array}$ & & \\
\hline $\begin{array}{c}\text { Fire } \\
\text { prevention }\end{array}$ & $\begin{array}{l}\text { Reduction in } \\
\text { the amount } \\
\text { of } \\
\text { accumulated } \\
\text { residual } \\
\text { biomass that } \\
\text { may cause } \\
\text { natural fires }\end{array}$ & Both & $\begin{array}{c}\text { Very } \\
\text { likely }\end{array}$ & Moderate & Positive & Yes & $\begin{array}{l}\text { The major positive } \\
\text { impact from the } \\
\text { mobilization of } \\
\text { charcoal waste and } \\
\text { other biomass } \\
\text { material that will } \\
\text { allow the increase of } \\
\text { raw material for } \\
\text { charcoal production, } \\
\text { which will reduce } \\
\text { the need for forest } \\
\text { clearing for energy } \\
\text { production and } \\
\text { prevention of forest } \\
\text { fires }\end{array}$ & $\begin{array}{c}\text { Stakeholder } \\
\text { consultation; } \\
{[27,28]}\end{array}$ & Yes & No & $\begin{array}{c}\text { No reliable } \\
\text { data }\end{array}$ & & \\
\hline
\end{tabular}


Table 3. Cont

\begin{tabular}{|c|c|c|c|c|c|c|c|c|c|c|c|c|c|}
\hline 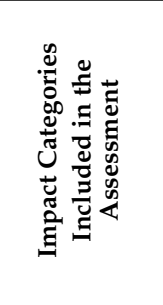 & 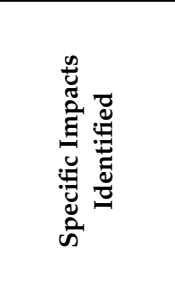 & 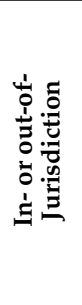 & 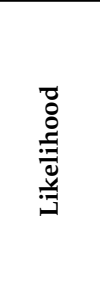 & 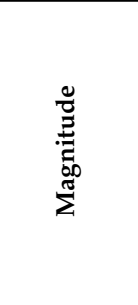 & 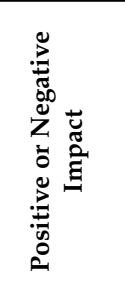 & 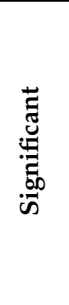 & 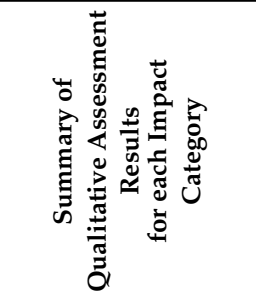 & 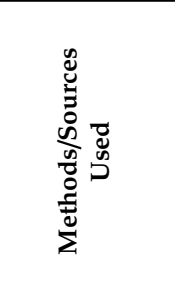 & 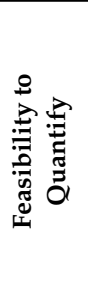 & 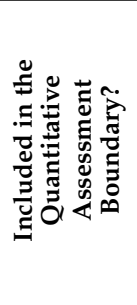 & 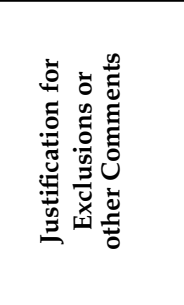 & 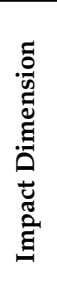 & $\begin{array}{l}\text { के } \\
\text { के }\end{array}$ \\
\hline $\begin{array}{c}\text { Water } \\
\text { availability }\end{array}$ & $\begin{array}{c}\text { Increased } \\
\text { water } \\
\text { available }\end{array}$ & & & & & & $n$ of the & & & & & & \\
\hline $\begin{array}{l}\text { Water } \\
\text { Quality }\end{array}$ & $\begin{array}{c}\text { Increased } \\
\text { amount of } \\
\text { available } \\
\text { water of } \\
\text { adequate } \\
\text { quality for } \\
\text { domestic use, } \\
\text { and } \\
\text { irrigation }\end{array}$ & Both & Likely & Moderate & Positive & Yes & $\begin{array}{l}\text { silting effects on } \\
\text { rivers and improved } \\
\text { ecosystem services } \\
\text { essential for water } \\
\text { quality and } \\
\text { availability }\end{array}$ & $\begin{array}{c}\text { Stakeholder } \\
\text { consultation } \\
\text { and } \\
\text { fieldwork } \\
\text { interview }\end{array}$ & N/A & No & $\begin{array}{c}\text { No reliable } \\
\text { data }\end{array}$ & & \\
\hline $\begin{array}{l}\text { Biodiversity } \\
\text { of terrestrial } \\
\text { ecosystems }\end{array}$ & $\begin{array}{l}\text { Increased } \\
\text { land areas } \\
\text { managed in } \\
\text { a sustainable } \\
\text { way and } \\
\text { reduction of } \\
\text { disturbance } \\
\text { of } \\
\text { ecosystems }\end{array}$ & In & $\begin{array}{l}\text { Very } \\
\text { likely }\end{array}$ & Major & Positive & Yes & $\begin{array}{l}\text { The major positive } \\
\text { impact of charcoal } \\
\text { production } \\
\text { technology. While } \\
\text { negative impacts do } \\
\text { exist, they are } \\
\text { insignificant }\end{array}$ & $\begin{array}{l}{[29] \text { and }} \\
\text { stakeholder } \\
\text { consultation }\end{array}$ & No & No & $\begin{array}{l}\text { No reliable } \\
\text { data/methods } \\
\text { available }\end{array}$ & & \\
\hline Soil & $\begin{array}{c}\text { Reduction of } \\
\text { eroded areas }\end{array}$ & In & $\begin{array}{l}\text { Very } \\
\text { likely }\end{array}$ & Major & Positive & Yes & $\begin{array}{l}\text { The major positive } \\
\text { impact of charcoal } \\
\text { production } \\
\text { technology. While } \\
\text { negative impacts do } \\
\text { exist, they are } \\
\text { insignificant }\end{array}$ & $\begin{array}{l}\text { Stakeholder } \\
\text { consultation }\end{array}$ & N/A & No & $\begin{array}{l}\text { No reliable } \\
\text { data/methods } \\
\text { available }\end{array}$ & & \\
\hline
\end{tabular}


Table 3. Cont

\begin{tabular}{|c|c|c|c|c|c|c|c|c|c|c|c|c|c|}
\hline 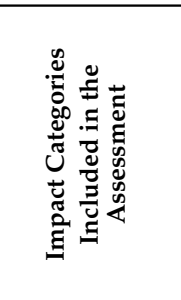 & 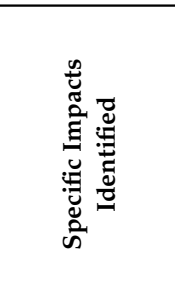 & 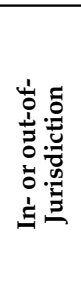 & 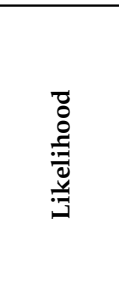 & 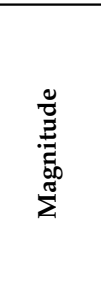 & 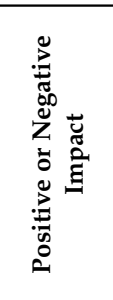 & 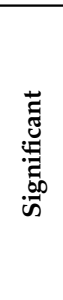 & 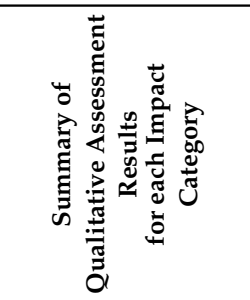 & 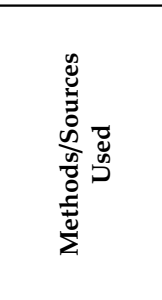 & 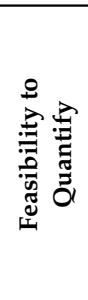 & 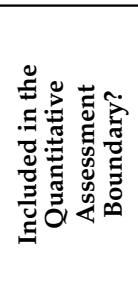 & 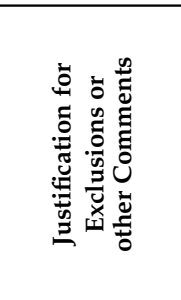 & 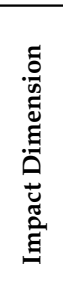 & in \\
\hline $\begin{array}{l}\text { The energy } \\
\text { produced in } \\
\text { a sustainable } \\
\text { manner }\end{array}$ & $\begin{array}{c}\text { Increased } \\
\text { access to } \\
\text { charcoal and } \\
\text { other energy } \\
\text { carriers } \\
\text { (briquettes, } \\
\text { torrefied } \\
\text { material) } \\
\text { produced in } \\
\text { a sustainable } \\
\text { way }\end{array}$ & Out & $\begin{array}{c}\text { Very } \\
\text { likely }\end{array}$ & Major & Positive & Yes & $\begin{array}{l}\text { The major positive } \\
\text { impact from } \\
\text { charcoal production } \\
\text { technology. While } \\
\text { negative impacts do } \\
\text { exist, they are } \\
\text { insignificant }\end{array}$ & $\begin{array}{l}\text { Stakeholder } \\
\text { consultation }\end{array}$ & Yes & Yes & $\begin{array}{l}\text { No reliable } \\
\text { data/methods } \\
\text { available }\end{array}$ & & \\
\hline \multirow[b]{2}{*}{$\begin{array}{c}\text { Air } \\
\text { quality/health } \\
\text { impact due } \\
\text { to air } \\
\text { pollution }\end{array}$} & $\begin{array}{l}\text { Reduction of } \\
\text { air pollution }\end{array}$ & & & & & & The major positive & Stakeholder & & & & & \\
\hline & $\begin{array}{l}\text { Reduction of } \\
\text { occupational } \\
\text { diseases in } \\
\text { the charcoal } \\
\text { production } \\
\text { sector }\end{array}$ & Both & Possible & Major & Positive & Yes & $\begin{array}{l}\text { production } \\
\text { technology. While } \\
\text { negative impacts do } \\
\text { exist, they are } \\
\text { insignificant }\end{array}$ & $\begin{array}{l}\text { consultation } \\
\text { and } \\
\text { fieldwork } \\
\text { interview }\end{array}$ & No & No & $\begin{array}{l}\text { No reliable } \\
\text { data/methods } \\
\text { available }\end{array}$ & & \\
\hline $\begin{array}{l}\text { Hunger, } \\
\text { nutrition and } \\
\text { food security }\end{array}$ & $\begin{array}{l}\text { Improved } \\
\text { access to } \\
\text { food in } \\
\text { quantity, } \\
\text { quality and } \\
\text { diversity }\end{array}$ & In & likely & Major & Positive & Yes & $\begin{array}{l}\text { The major positive } \\
\text { impact of charcoal } \\
\text { production is the } \\
\text { possibility of } \\
\text { increasing revenues } \\
\text { and investments } \\
\text { with NAMA } \\
\text { alternative } \\
\text { income-generating } \\
\text { activities. While } \\
\text { negative impacts do } \\
\text { exist, they are } \\
\text { insignificant. }\end{array}$ & $\begin{array}{l}\text { Stakeholder } \\
\text { consultation }\end{array}$ & No & No & $\begin{array}{l}\text { No reliable } \\
\text { data/methods } \\
\text { available }\end{array}$ & & \\
\hline
\end{tabular}


Table 3. Cont

\begin{tabular}{|c|c|c|c|c|c|c|c|c|c|c|c|c|c|}
\hline 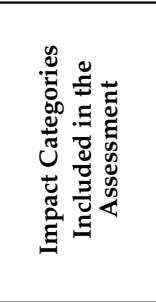 & 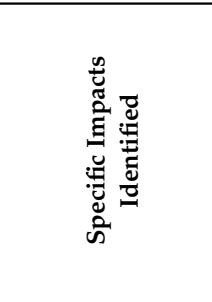 & 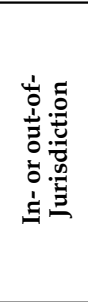 & 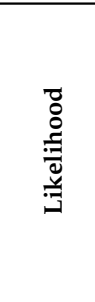 & 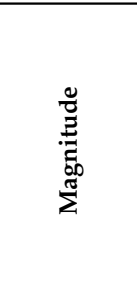 & 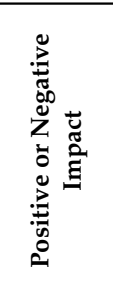 & 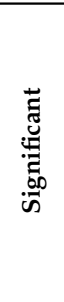 & 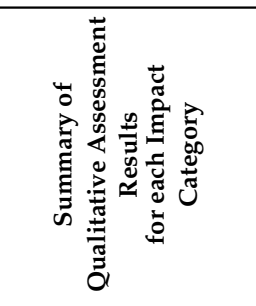 & 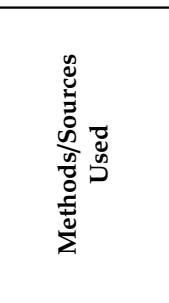 & 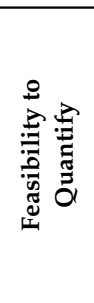 & 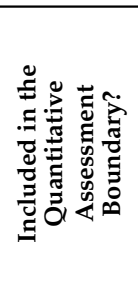 & 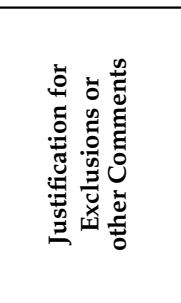 & 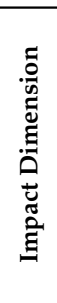 & की \\
\hline \multirow{3}{*}{ Education } & $\begin{array}{l}\text { Improved access } \\
\text { to education for } \\
\text { local children }\end{array}$ & In & Likely & Major & Positive & Yes & \multirow{3}{*}{$\begin{array}{l}\text { Increased income } \\
\text { for local people is } \\
\text { expected, thereby } \\
\text { investing in child } \\
\text { education and } \\
\text { awareness for all } \\
\text { relevant actors in } \\
\text { the charcoal value } \\
\text { chain. While } \\
\text { negative impacts do } \\
\text { exist, they are } \\
\text { insignificant. }\end{array}$} & $\begin{array}{l}\text { Stakeholder } \\
\text { consultation }\end{array}$ & Yes & Yes & Included & & \\
\hline & $\begin{array}{l}\text { Improved ability } \\
\text { to produce } \\
\text { charcoal } \\
\text { sustainably by } \\
\text { capacity, skills, } \\
\text { and knowledge } \\
\text { development }\end{array}$ & In & $\begin{array}{c}\text { Very } \\
\text { likely }\end{array}$ & Major & Positive & Yes & & $\begin{array}{l}\text { Stakeholder } \\
\text { consultation }\end{array}$ & No & No & $\begin{array}{l}\text { No reliable } \\
\text { data/methods } \\
\text { available }\end{array}$ & & \\
\hline & $\begin{array}{l}\text { Increased } \\
\text { number of } \\
\text { people aware of } \\
\text { climate change, } \\
\text { training and } \\
\text { research }\end{array}$ & In & Likely & Moderate & Positive & Yes & & $\begin{array}{l}\text { Stakeholder } \\
\text { consultation }\end{array}$ & Yes & No & $\begin{array}{l}\text { No reliable } \\
\text { data/methods } \\
\text { available }\end{array}$ & & \\
\hline $\begin{array}{l}\text { Access to } \\
\text { land and its } \\
\text { resources }\end{array}$ & $\begin{array}{l}\text { Increased legal } \\
\text { access to land } \\
\text { and its resources }\end{array}$ & In & Likely & Moderate & Positive & Yes & $\begin{array}{l}\text { Secure land access } \\
\text { will be enhanced as } \\
\text { NAMA includes } \\
\text { land certification. } \\
\text { Secure land rights } \\
\text { enable safe and } \\
\text { long-term } \\
\text { investments }\end{array}$ & \multirow{2}{*}{$\begin{array}{l}\text { Stakeholder } \\
\text { consultation }\end{array}$} & Yes & No & $\begin{array}{l}\text { No reliable } \\
\text { data/methods } \\
\text { available }\end{array}$ & & \\
\hline $\begin{array}{l}\text { Poverty } \\
\text { reduction }\end{array}$ & $\begin{array}{c}\text { Reduction of } \\
\text { poverty of } \\
\text { households in } \\
\text { NAMA covered } \\
\text { areas }\end{array}$ & & $\begin{array}{c}\text { Very } \\
\text { likely }\end{array}$ & High & Positive & Yes & $\begin{array}{l}\text { The major positive } \\
\text { impact of charcoal } \\
\text { production is the } \\
\text { possibility of } \\
\text { increasing revenues } \\
\text { and investments } \\
\text { with NAMA } \\
\text { alternative } \\
\text { income-generating } \\
\text { activities. }\end{array}$ & & Yes & No & $\begin{array}{l}\text { No reliable } \\
\text { data/methods } \\
\text { available }\end{array}$ & & \\
\hline
\end{tabular}


Table 3. Cont

\begin{tabular}{|c|c|c|c|c|c|c|c|c|c|c|c|c|c|}
\hline 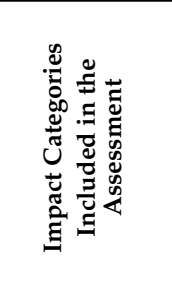 & 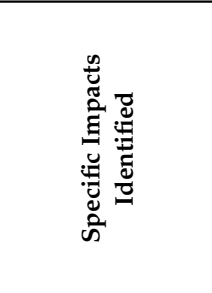 & 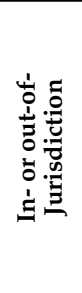 & 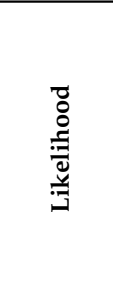 & 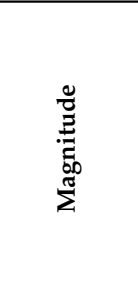 & 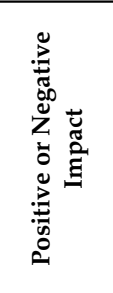 & 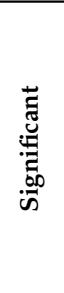 & 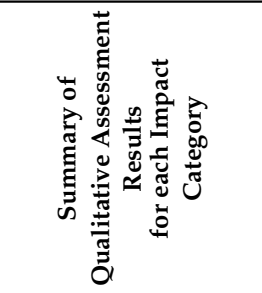 & 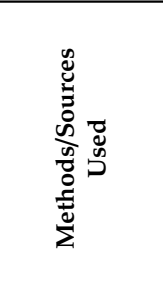 & 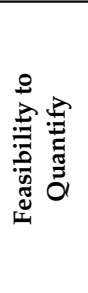 & 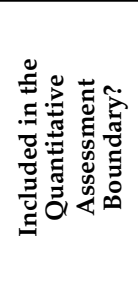 & 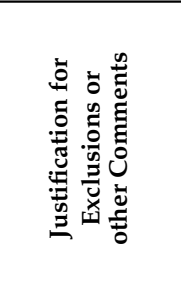 & 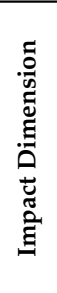 & की \\
\hline \multirow[t]{2}{*}{$\begin{array}{l}\text { Gender } \\
\text { equality and } \\
\text { equity }\end{array}$} & $\begin{array}{c}\text { Increased } \\
\text { gender equality } \\
\text { promotion and } \\
\text { women } \\
\text { empowerment } \\
\text { by created } \\
\text { association }\end{array}$ & In & Likely & Moderate & Positive & Yes & \multirow{2}{*}{$\begin{array}{l}\text { NAMA will increase } \\
\text { opportunities and } \\
\text { fair and equitable } \\
\text { sharing of benefits }\end{array}$} & $\begin{array}{l}\text { Stakeholder } \\
\text { consultation }\end{array}$ & No & No & $\begin{array}{l}\text { No reliable } \\
\text { data/methods } \\
\text { available }\end{array}$ & & \\
\hline & $\begin{array}{l}\text { Improving } \\
\text { income and } \\
\text { opportunity } \\
\text { equity }\end{array}$ & In & Possible & Moderate & Positive & Yes & & $\begin{array}{l}\text { Stakeholder } \\
\text { consultation }\end{array}$ & Yes & Yes & Included & & \\
\hline $\begin{array}{l}\text { Time spent } \\
\text { on working }\end{array}$ & $\begin{array}{l}\text { Reduced time on } \\
\text { labor activities }\end{array}$ & In & Possible & Major & Positive & Yes & $\begin{array}{l}\text { NAMA will allow } \\
\text { the producers to } \\
\text { spend their time in } \\
\text { other activities for } \\
\text { their livelihood }\end{array}$ & $\begin{array}{l}\text { Stakeholder } \\
\text { consultation }\end{array}$ & Yes & Yes & $\begin{array}{l}\text { No reliable } \\
\text { data/methods } \\
\text { available }\end{array}$ & & \\
\hline $\begin{array}{l}\text { Economic } \\
\text { diversity }\end{array}$ & $\begin{array}{l}\text { Increase of } \\
\text { companies } \\
\text { associated with } \\
\text { the sector }\end{array}$ & Both & Likely & Major & Positive & Yes & \multirow{2}{*}{$\begin{array}{l}\text { New economic } \\
\text { activities and } \\
\text { strengthening and } \\
\text { promoting the } \\
\text { growth of new } \\
\text { industries. Major } \\
\text { positive impact from } \\
\text { charcoal production } \\
\text { technology. While } \\
\text { negative impacts do } \\
\text { exist, they are } \\
\text { insignificant }\end{array}$} & $\begin{array}{l}\text { Stakeholder } \\
\text { consultation }\end{array}$ & Yes & No & $\begin{array}{l}\text { No reliable } \\
\text { data/methods } \\
\text { available }\end{array}$ & & \\
\hline Labor (jobs) & $\begin{array}{l}\text { Increased } \\
\text { number of } \\
\text { employed } \\
\text { people in the } \\
\text { charcoal value } \\
\text { chain (green } \\
\text { jobs) } \\
\end{array}$ & In & Likely & Moderate & Positive & Yes & & $\begin{array}{l}\text { Stakeholder } \\
\text { consultation }\end{array}$ & Yes & Yes & Included & & \\
\hline
\end{tabular}


Table 3. Cont

\begin{tabular}{|c|c|c|c|c|c|c|c|c|c|c|c|c|c|}
\hline 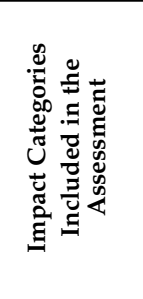 & 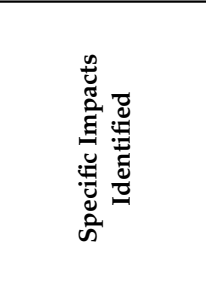 & 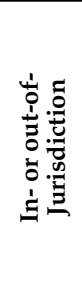 & 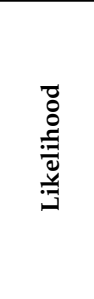 & 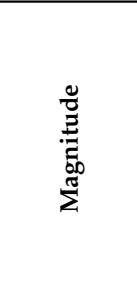 & 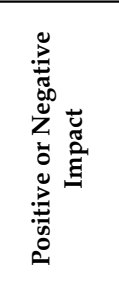 & 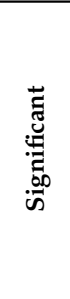 & 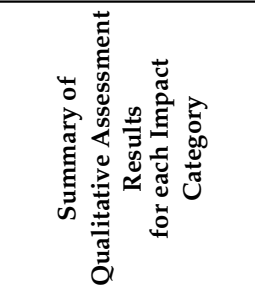 & 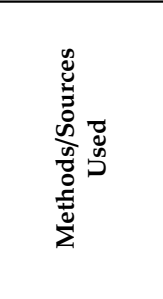 & 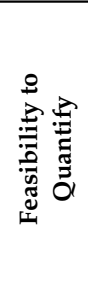 & 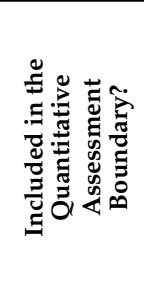 & 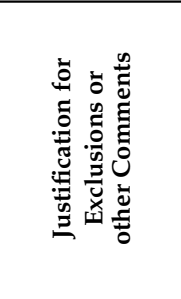 & 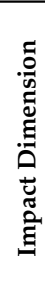 & \\
\hline Income & $\begin{array}{l}\text { increase in } \\
\text { per-capita } \\
\text { income from } \\
\text { green jobs }\end{array}$ & Both & Likely & Moderate & Positive & Yes & \multirow{3}{*}{$\begin{array}{l}\text { Increase in revenue } \\
\text { of different actors } \\
\text { involved in the } \\
\text { charcoal value chain } \\
\text { and the charcoal } \\
\text { sector's } \\
\text { formalization. }\end{array}$} & $\begin{array}{l}\text { Stakeholder } \\
\text { consultation }\end{array}$ & Yes & Yes & Included & & \\
\hline Income & $\begin{array}{c}\text { Local } \\
\text { communities } \\
\text { will receive } 20 \% \\
\text { of the shared } \\
\text { revenue of } \\
\text { charcoal } \\
\text { licensing. }\end{array}$ & In & Likely & Moderate & Positive & Yes & & $\begin{array}{l}\text { Stakeholder } \\
\text { consultation }\end{array}$ & Yes & Yes & Included & & \\
\hline Revenue & $\begin{array}{l}\text { Increase in total } \\
\text { revenue in the } \\
\text { sector (\% GDP) }\end{array}$ & Both & Likely & Moderate & Positive & Yes & & {$[10,21]$} & Yes & Yes & Included & & \\
\hline $\begin{array}{l}\text { Costs of } \\
\text { health care }\end{array}$ & $\begin{array}{l}\text { Reduction on } \\
\text { economic costs } \\
\text { of health losses }\end{array}$ & In & $\begin{array}{c}\text { Very } \\
\text { likely }\end{array}$ & Major & Positive & Yes & $\begin{array}{l}\text { Reduction of } \\
\text { occupational } \\
\text { diseases in the sector } \\
\text { and health costs } \\
\text { associated are major } \\
\text { positive impacts for } \\
\text { exposed people }\end{array}$ & $\begin{array}{l}\text { Stakeholder } \\
\text { consultation }\end{array}$ & No & No & $\begin{array}{l}\text { No reliable } \\
\text { data/methods } \\
\text { available }\end{array}$ & & \\
\hline
\end{tabular}




\subsection{Quantitative Assessment of Emission Reductions of the Charcoal NAMA}

\subsubsection{Introducing Modern Kilns and Sustainable Forest Management}

Figure 2 revealed that the efficient kilns (EK) and sustainable forest management (SFM) have high emission reduction potential compared to the baseline (BAU) scenario at the pilot and national levels. Figure 2A shows that at the national level, introducing EK and SFM will reduce emissions by about $117,443 \pm 17,166$ t CO$_{2}$-eq (45\%) ( $\pm 95 \%$ confidence interval) in 2025 . The overall average emission reduction in 2030 is approximately 175,125 $\pm 10,622 \mathrm{t} \mathrm{CO}_{2}$-eq reducing $45 \%$ from BAU emission. At the pilot area, the EK and SFM have the potential of emission reduction in $66 \%\left(142,627 \pm 8364 \mathrm{t} \mathrm{CO}_{2}\right.$-eq) by 2030 , and in 2025 this technology yields potential emission reductions of 93,309 $\pm 13,069$ t $\mathrm{CO}_{2}$-eq $(64 \%)$, (Figure 2B). These figures revealed that introducing EK and SFM had a higher impact on emission reduction in the pilot area than the national level.
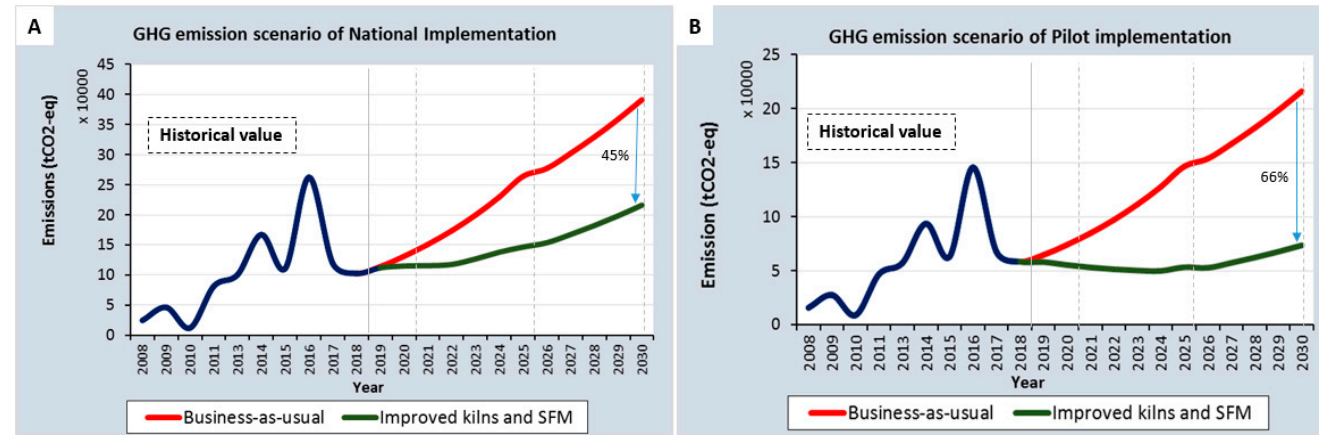

Figure 2. Business-As-Usual (BAU) and potential emission reduction scenarios introduce efficient kilns and sustainable forest management (SFM) from NAMA implementation at (A) national and (B) sub-national level.

\subsubsection{Briquetting Charcoal Waste Materials}

The figures of the BAU scenario presented in the earlier section are applicable in this scenario as well. Figure $3 \mathrm{~A}$ revealed that at the national level, briquette charcoal waste could reduce the emission by $55 \%\left(144,459 \pm 21,185 \mathrm{t} \mathrm{CO}_{2}\right.$-eq; $\pm 95 \%$ of confidence interval) by 2025 . The average emission reduction of briquetting in 10 years from 2020 to 2030 is roughly to $214,112 \pm 13,032$ t $\mathrm{CO}_{2}$-eq $(55 \%)$ by introducing $80 \%$ of briquetting of charcoal waste as a mitigation option. Figure $3 \mathrm{~B}$ shows that the impact of briquetting is very high at the pilot project scale, revealing that briquetting, in addition to being a reasonably cheap measure to implement, also has a high potential for emission reduction. Overall, briquetting reduces emissions by $70 \%$ or $102,573 \pm 14,099 \mathrm{t} \mathrm{CO}_{2}$-eq up to 2025 , and the emission reduction by 2030 is about $172,904 \pm 20,370$ t $\mathrm{CO}_{2}$-eq ( $80 \%$ of emission reduction potential).
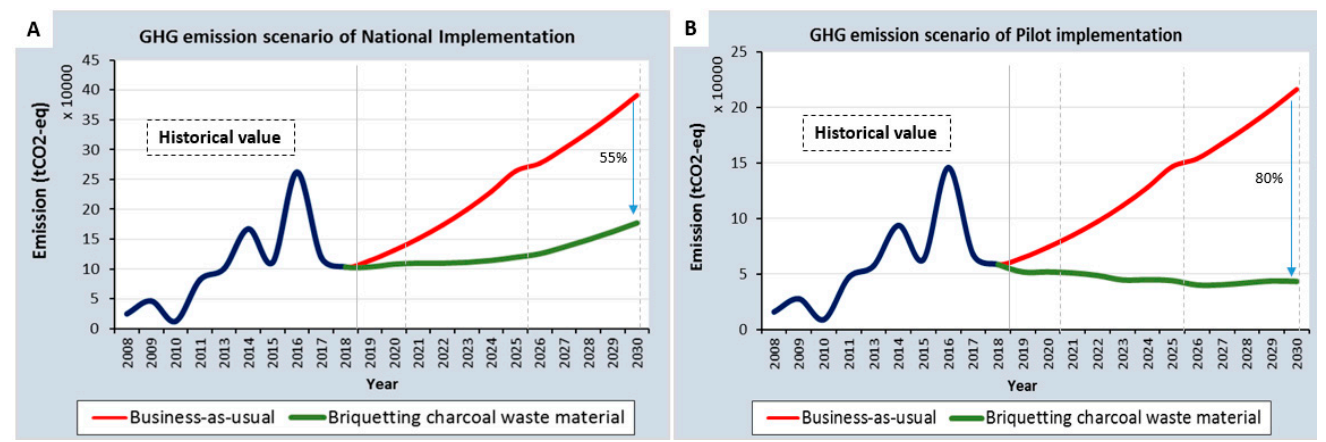

Figure 3. Business-As-Usual (BAU) and potential emission reduction scenarios of briquetting charcoal wastes material forest management from NAMA implementation at (A) national and (B) sub-national level. 
The potential emission reduction of briquette charcoal waste is much higher than that of EK and SFM. However, EK and SFM include several small mitigation activities (e.g., selected harvesting, many left standing trees, promotion of natural regeneration, etc.) that will reduce the emissions of $\mathrm{CO}_{2}$ meaningfully by increasing removal sources. However, briquette charcoal waste directly impacts emission reduction by using the residuals from old kilns and can use other wood residuals from the forest for briquetting. This can bring a considerable emission reduction when the optimistic scenario (100\% of charcoal producers in the pilot area and at the national level will adopt briquetting) is implemented.

\subsubsection{Torrefaction}

Torrefaction has revealed itself that it does not have a high potential for emission reduction. Figure $4 \mathrm{~A}$ suggests that the implementation of torrefaction will lead to an average emission reduction in the pilot area about $54,812 \pm 6,787 \mathrm{t} \mathrm{CO}_{2}$-eq ( $\pm 95 \%$ of confidence interval), which represents $37 \%$ of emission reduction by 2025, and the emission reduction reached $55,659 \pm 3,112 \mathrm{t} \mathrm{CO}_{2}$-eq by 2030 . At the national level, the emission reduction was about 52,622 $\pm 1,572$ t $\mathrm{CO}_{2}$-eq up to 2025, and in 2030 the emission reduction reached 53,470 $\pm 1,572 \mathrm{t} \mathrm{CO}_{2}$-eq (Figure 4B). The lower emission reduction of torrefaction can be explained by the assumption applied in this study, which has considered that few companies will be willing to adopt this technology due to market instability.
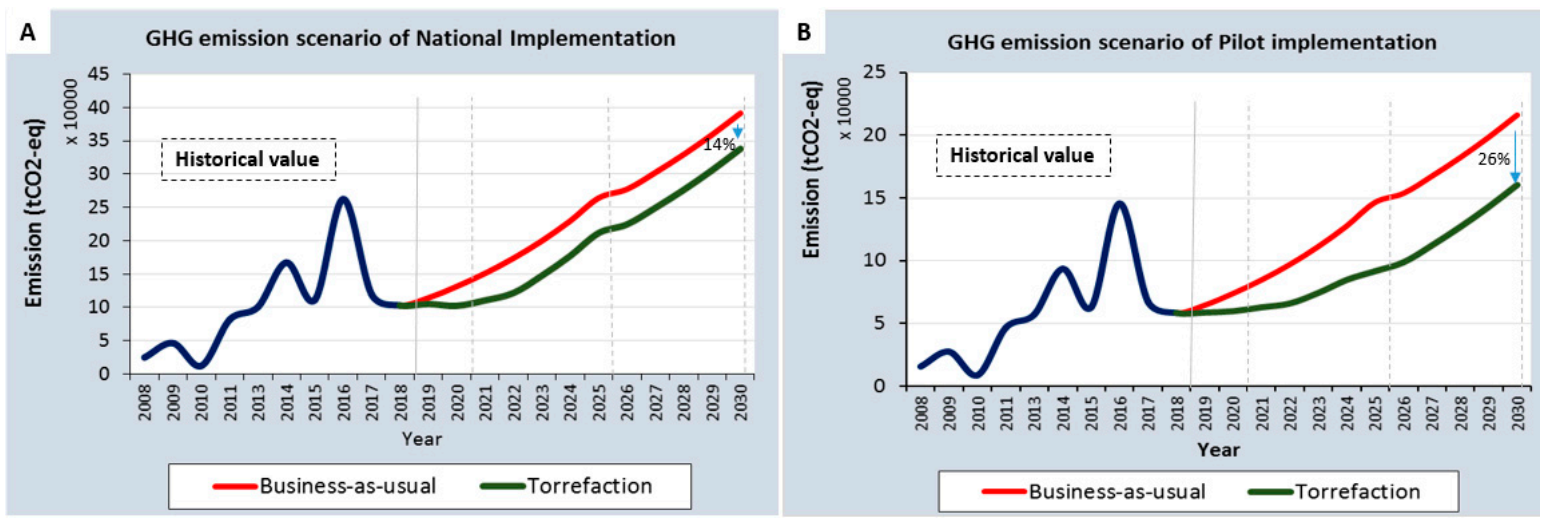

Figure 4. Business-As-Usual (BAU) and potential emission reduction scenarios of torrefaction from NAMA implementation at (A) national and (B) sub-national level.

\subsubsection{Greenhouse Gas Emission from Charcoal Transportation}

According to the field study results, most wholesalers come from urban areas and usually own trucks. However, some have to rent trucks and licenses or transport charcoal with the train that passes Mabalane once a week. The estimated emission of charcoal transportation in Mabalane is about $25.75 \mathrm{t}$ $\mathrm{CO}_{2}$ per ton of charcoal from the charcoal production site to the railway, and $25.71 \mathrm{t} \mathrm{CO}_{2}$ per ton charcoal transport from the production unity to Maputo city (Table 4).

Table 4. Emission from charcoal transport from the production area to the railway and the prominent market (Maputo city).

\begin{tabular}{ccc}
\hline District & $\begin{array}{c}\text { Emission of Charcoal Transportation from } \\
\text { Production Unity to the Railway Station }\end{array}$ & $\begin{array}{c}\text { Emission of Charcoal Transportation } \\
\text { from Production Unity to Maputo City }\end{array}$ \\
\cline { 2 - 3 } & $\mathbf{t ~ C O}_{\mathbf{2}}$ Per Ton of Charcoal & $\mathbf{t ~ C O}_{\mathbf{2}}$ Per Ton of Charcoal \\
\hline Chicualacuala & 8.38 & 14.41 \\
Mabalane & 6.63 & 11.31 \\
Massingir & 3.75 & - \\
Guijá & 6.99 & - \\
Total emission $\left(\mathrm{t} \mathrm{CO}_{2}\right)$ & 25.75 & 25.71 \\
\hline
\end{tabular}


The BAU scenario suggests that charcoal transportation will increase by 128 tCO2-eq, corresponding to an $80 \%$ increase from 2020 to 2030 (Figure 5). The assumption is that the new technology will increase the charcoal production efficiency and the final amount of charcoal produced. Hence, the required amount of charcoal to the market will also increase. This will result in higher fuel consumption and higher emissions. However, the NAMA could achieve reductions in fossil-fuel use by optimizing the transport mode, reducing the distance between wood sources, carbonization plants, and consumption centers, as well as the efficient handling of the product. Figure 5 also indicates that the average emission of transportation up to 2025 will lead to a 50\% increase in emissions $(54 \pm 7.6 \mathrm{t}$ $\mathrm{CO}_{2}$-eq, $\pm 95 \%$ of confidence interval), and by 2030 the average emission is about $128 \pm 8.4 \mathrm{tCO}_{2}$-eq $(80 \%)$. These figures reveal that the amount of transport $\mathrm{CO}_{2}$ emissions when all NAMA option is being implemented are relatively small, compared to the overall emissions of charcoal production, even though the envisioned percentage of increased emissions is considerable. Given the impact of transport emissions on the net amount of emission reduction potential of each NAMA technology, considering the uncertainty analysis, transport emissions become so negligible that they are here omitted from the analysis. Although having these numbers available might prove useful for future research. The lower amount of transportation emissions reported in this study is in line with that found in the literature. Furthermore, Food and Agriculture Organization (FAO) [30] stated that transportation has relatively little impact on total GHG emissions in the charcoal production value chain.

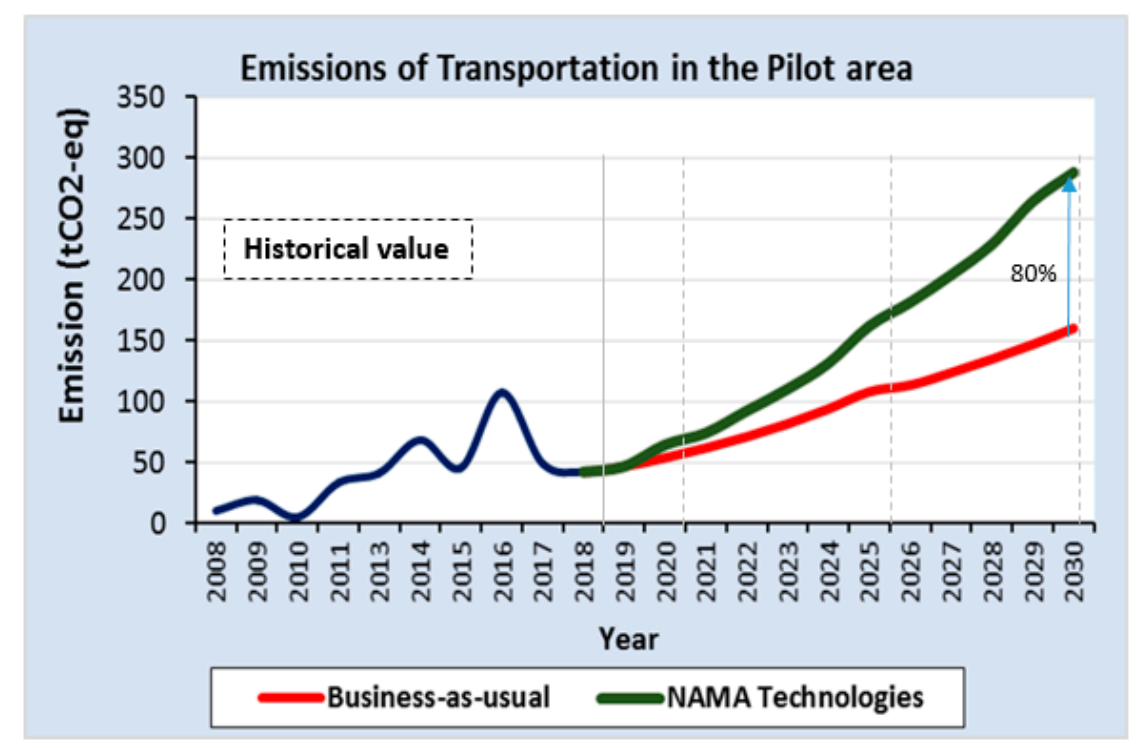

Figure 5. Business-as-usual and potential emission scenarios from charcoal transportation from the pilot area to the consumption area in Maputo and Matola cities.

\subsubsection{Cumulative Emission Reduction Scenario of all Selected NAMA's Technologies}

Figure 6 reveals that if all the technologies are implemented in combination, they will potentially deliver large emission reductions, reaching already in the first 2 years net-zero emissions than the $\mathrm{BAU}$, and achieving subsequently net sequestration. It is expected that they could cumulatively reduce emission by roughly $314,521 \pm 45,138 \mathrm{tCO}_{2}$-eq $(119 \%)$ by 2025 , and $442,706 \pm 26,766 \mathrm{tCO}_{2}$-eq or $113 \%$ by 2030 at the national level (Figure 6A). At the pilot level, the technologies' implementation would lead to $371,191 \pm 28,740 \mathrm{t} \mathrm{CO}_{2}$-eq $(172 \%)$ of emission reduction up to 2030 , while in 2025 , the emission reduction will reach $250,694 \pm 30,306 \mathrm{t} \mathrm{CO}_{2}$-eq $(171 \%)$. The amount of cumulative emission reduction is exceptionally high, highlighting the impact of briquetting, which had the highest emission reduction amongst the three technologies. 

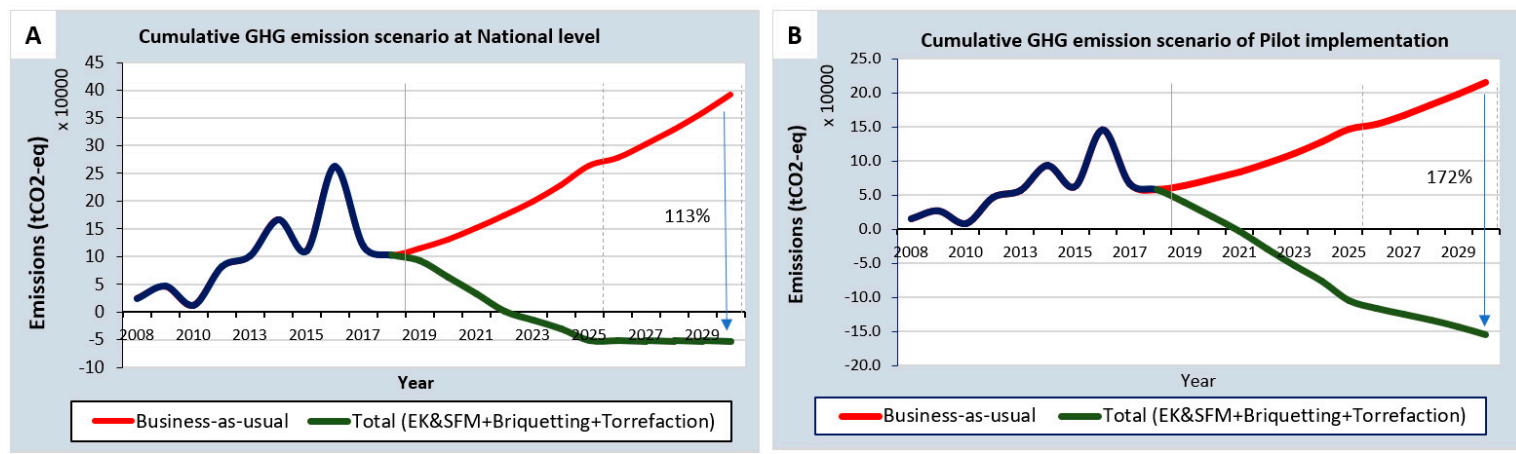

Figure 6. Cumulative emission reduction potential scenario from all technologies: (A) improved kilns and sustainable forest management plus briquette charcoal waste against its (B) business-as-usual scenario.

\subsection{Quantitative Assessment of Social and Economic Impact Categories of the Charcoal NAMA}

The qualitative evaluation has revealed that job creation, charcoal consumers, gender balance, revenues, revenues in GDP, and education were the significant impact categories of NAMA, and its scenario developed (Figure 7). The contribution of the forestry sector to the country's GDP will increase by up to $10 \%$ by 2030 (Figure 7A) due to NAMA's implementation. The number of women in the charcoal value chain will increase from $10 \%$ (43,335 women) in 2019 to $39 \%(89,605$ women) by 2030 (Figure 7B). NAMA will contribute to increased employment at the national level by $23 \%$ in 2025 and $15 \%$ by 2030 (Figure 7C), and increased revenue for the District Services of Economic Activities (SDAE) by about 825,000 USD in 2025 and 1.6 million USD by 2030, with 165,000 USD per year going to the communities in 2025, and 331,000 USD per year in 2030, as their 20\% shares of license revenue (Figure 7F). The percentage of charcoal consumers using sustainably produced charcoal will increase by $21 \%$ by 2025 to $78 \%$ by 2030 with NAMA (Figure 7D). The NAMA will increase income opportunities by about $20 \%$ and $16.5 \%$ allowing parents to invest in education. An increased number of children enrolled in the school from 242,000 in 2025 to 272,377 children by 2030 (Figure 7E).
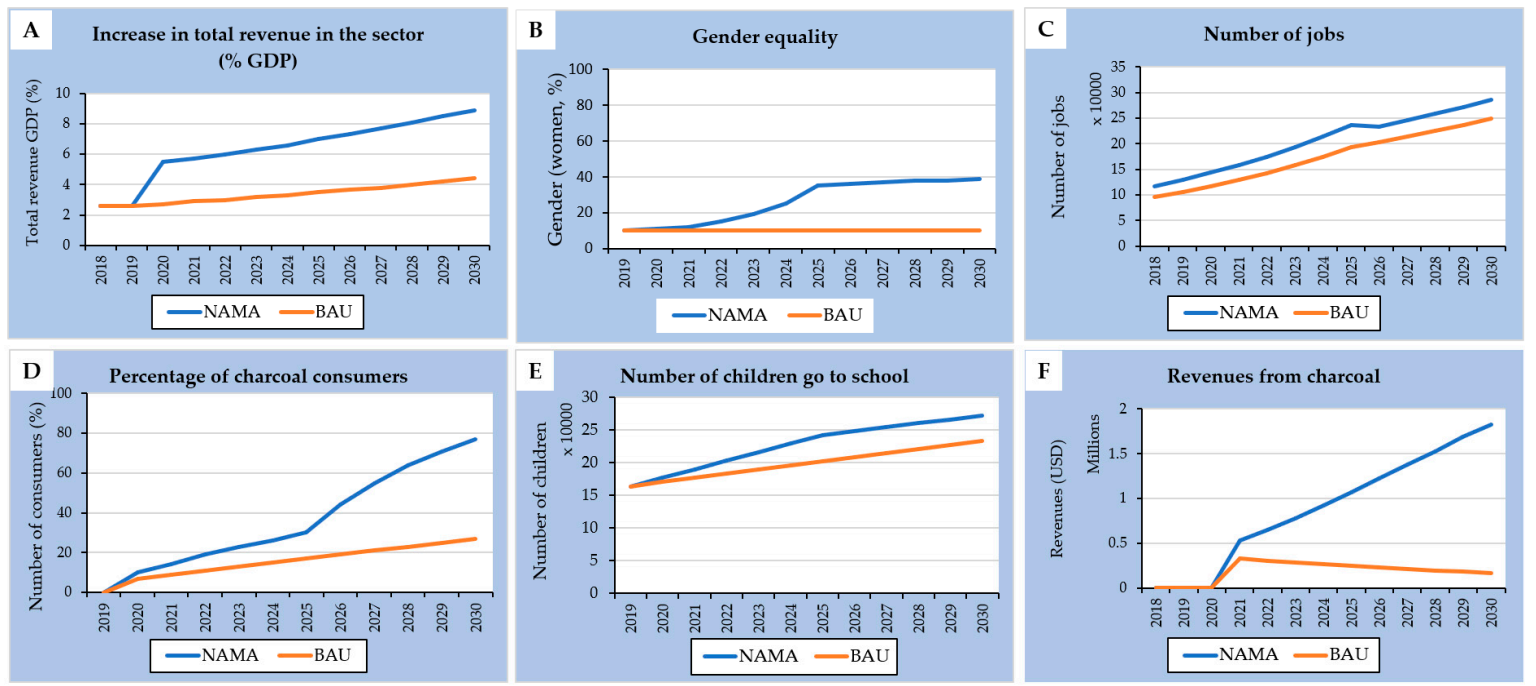

Figure 7. A quantitative assessment of the social and economic benefit of charcoal NAMA. (A) increase in total revenues in the sector (\% GDP); (B) gender equality; (C) number of jobs; (D) percentage of charcoal consumers; (E) number of children go to school; (F) revenues from charcoal.

\subsection{Validation of the Impact}

The charcoal producers confirmed all significant and relevant impact indicators during the fieldwork. From the focus group discussion held at the district level, one of the charcoal producers said 
they produce charcoal to sell and obtain financial resources. With this revenue, they purchase food, pay their children's education expenses, and household expenses as there are no favorable conditions for agriculture activity due to lack of rain. References to low capacity to manage community funds, and poor working conditions, resulting from a lack of proper tools for cutting the trees for charcoal production and tools to protect against smoke from the carbonization process. Almost all interviewed charcoal producers are willing to implement the NAMA to increase the rotation of charcoal production and, consequently, increase charcoal production efficiency.

The District Services of Economic Activities (SDAE), the key stakeholder at the district level, stated that there is now a restriction for external licensed charcoal producers in the district covered by the study. Community members produced charcoal and sold to intermediaries who have the financial capacity and are legally licensed to transport charcoal. Charcoal producers (members of existing charcoal associations) and charcoal traders perceive the NAMA to have the potential to contribute to an increase in charcoal producers' income and forest sector revenue from taxation since the formalization of the charcoal value chain will allow local producers to have a secured market.

We raised here that the district currently does not receive the charcoal licensing revenue, which is collected at the provincial level and channeled to the Ministry of Finance. The local community cannot conduct monitoring and patrolling services due to limited financial and technical capacity. Another issue that was raised is the limitation of licensing to local producers comparing to external operators. Although this might be seen as unfavorable for potential external operators (license holders) as it will reduce their potential income, the NAMA concept positively impacts both sides. Local charcoal producers will have an opportunity to increase their income, and the external operators will benefit from other parts of the chain, such as transport and a secure market. Balanced benefits between charcoal producers and license holders will be one of the results of the NAMA implementation.

\section{Discussion}

\subsection{Potential of Charcoal NAMA for Greenhouse Gas Emission Reduction}

We believe that the three NAMA options together maximize their impact for several reasons related to forest growth, carbonization, and the feedstock needed for charcoal production. According to [31], there are three categories of promising forestry practices that promote sound management of forests and at the same time conserve and sequester carbon (C): (1) management for conservation of existing $\mathrm{C}$ pools through slowing deforestation, changing harvesting regimes and protecting forests from disturbances; (2) management for expanding $C$ storage by increasing the area and/or C, density of native forests, plantations and agroforestry, and in wood products; and (3) management for substitution by increasing the transfer of forest biomass $C$ into products, such as biofuels and long-lived wood products, that can be used instead of fossil-fuel based products. The three NAMA options are somehow related to these three stated categories, and the emission scenarios show that the three NAMA selected options at the same time will yield a negative emission scenario from BAU. This suggests that the SFM will reduce the emissions through regeneration regrowth and forest management. For instance, Sedano et al. [7] reported 549,483 Mg of above-ground biomass removals in mopane woodland, north of the Mabalane district. Regeneration is an essential parameter to $\mathrm{CO}_{2}$ removals in the forest area. However, Mwampamba et al. [32] suggested that the volume of woody biomass removed in harvests can be regrown in as little as 15 years in Miombo woodland, depending on soils, climate, and other factors and whether regeneration is allowed to occur. This suggests that the maximum impact of SFM on emission reduction, mainly through regeneration, will be perceived much later than is thought. Still, regenerated trees will sequester $\mathrm{CO}_{2}$ during the growth process, primarily from surrounding areas [33]. On the other hand, the NAMA technologies will reduce the emission mainly from carbonization. In the extensive literature review on charcoal, FAO [30] concluded that a shift from traditional kilns to highly efficient modern kilns could reduce GHG emissions in the value chain by $80 \%$. Therefore, the amount of cumulative emission reduction reported in this study can reveal the magnitude of NAMA charcoal 
options' impact. Still, other issues, particularly financially and capacity building, need to be considered to make these emission reductions achievable [11]. Additionally, considering agroforestry systems as some of the options to be implemented together with NAMA options could, in part, overcome one of the main challenges of emission reduction from deforestation and forest degradation in the rural areas of Mozambique.

Mozambique NDC to the UNFCCC states a target reduction in about $31.19 \mathrm{Mt} \mathrm{CO}_{2}$ from 2020 to 2025 [34]. Significant contributions to this target's achievement will be from the forest and land-use sector, with measures such as combating deforestation, promotion of forest restoration under the NAMA, and other sustainable biomass use and conservation strategies. Amongst the scenarios, briquetting charcoal waste presents the highest potential of $\mathrm{CO}_{2}$ emission reduction, followed by efficient kilns and sustainable forest management options. The higher amount of charcoal waste left on the ground during the charcoal production nowadays is an advantage for the briquetting scenario. Torrefaction showed the least potential for emission reduction as a result of more conservative assumptions in scenario development. However, the carbon price has a key role in developing a low-carbon society, and sustainable initiatives are not always encouraged in the presence of its low value [35].

Torrefaction might be challenging for implementation for several reasons as following: (i) there are conditions not yet created in terms of legislation; (ii) no clear policy and technical norms for the use of biomass residues from forest logging (native and planted forest); (iii) no incentives for dedicated energy plantations; and (iv) high cost of torrefaction technology [11]. The National Reforestation Strategy becomes a feasible option. Studies have referred that in Mozambique, biomass from dedicated energy crops, logging, and wood processing residues can generate around 6.7 EJ [36]. A survey of the potential of logging residues from indigenous and planted species in Mozambique estimated based on total availability biomass and wood fuel quality around 84.5 PJ that can be recovered from the utilization of logging residues [37]. Based on this information, the recovery and utilization of waste biomass and the promotion of dedicated energy plantations would benefit Mozambique from a climate perspective. However, detailed data about the intended species, production system, and technology efficiency levels need to be clarified for robust estimates for the torrefaction scenario.

Overall, the potential of the $\mathrm{CO}_{2}$ emission scenario estimated in this study showed that NAMA is a mitigation tool in the charcoal sector with social and economic significant positive impacts. However, its implementations depend on the financial resources, technology, and capacity-building support, mainly at the community or local level, where charcoal production occurs. Cucchiella et al. (2020) recommended that the decision-makers cannot only be interested to reach an environmental improvement or socio-economic opportunity. Still, the equilibrium between these three aspects is the final goal of reaching the principle of sustainability [35].

\subsection{Insights for Robust and Transparent Emission Estimates for the Charcoal Sector}

Robust estimates are only possible with systematic and consistent data, which is not always available. Generation of new activity data is seen as the most challenging process as most of the existing MRV systems are established to accommodate the needs and existing policies rather than collecting new data. Improvement in data gathering and information flows to appropriate levels will be needed for a continuous and robust assessment of the NAMA impacts. Such advances will require capacity building and reporting guidance to charcoal producers and training of district-level forest service officers in methodologies and procedures for data, reporting, and monitoring.

This study's main objective is to assess the ICAT guidance's applicability to achieve the ETF through an assessment of the NAMA. The results provided an excellent basis to discuss the contribution of sustainable charcoal production or sustainable use of biomass energy in emission reduction and their social and economic impact on a local and national scale. Moreover, this study discusses the challenges and issues, mostly about data quality and sharing, and identified sector solutions to overcome them. 
The ICAT guidance offers an opportunity to improve the scientific measurement of such an incentive system - either by direct use for countries needing to adopt a comprehensive approach or as a starting point of comparison for improving existing national policy or action. One of Mozambique's critical challenges to establishing sustainable institutional frameworks at national, sectoral, and subnational levels for data collection and reporting to the ETF is creating an institutional system that supports the collection, exchange, storage, and use of relevant data across national institutions. From this study and other reports, we listed several gaps and needs related to the management of data: (i) dispersal of data across national agencies; (ii) lack of arrangements for data monitoring and reporting; (iii) hesitation to share data between public and private institutions; (iv) time delays in gathering and accessing data; and (v) dependence on informal data-sharing and collection agreements.

Mozambique is aware of the limited in-country capacity to implement the modalities, procedures, and guidelines (MPGs) of the Paris Agreement's ETF, and this capacity gap cannot improve solely based on the ad-hoc provision of capacity-building by external actors. Thus, the country sees a strategy to develop a training program on the ETF focus areas. This program will enhance the capacity of the current and future members of the Inter-institutional Group on Climate Change, with the vision of building a strong and cohesive group of climate change aware technicians. They can ensure that reporting on climate change action and support is sustainable over time.

The country is moving forward on institutionalizing the arrangements for collecting and providing data for the national MRV system. This will require a consultative process with all stakeholders, involving both technicians and higher-level ministerial staff, and will result in the attribution of formal mandates and responsibilities for the different institutions. Institution's mandates will then be enshrined in a legal instrument. This study has highlighted several issues that need further support to improve the data to feed the MRV system. Firstly, the national MRV do not cover all the necessary details for monitoring charcoal production and its associated deforestation and forest degradation $[6,7,13]$. Secondly, there is limited capacity of the institutions and actors that should be part of this national system. To overcome this barrier, it is recommended to establish formal institutional arrangements for climate transparency activities; secure sustainable capacity-building efforts in the country through the development of a training program. The training should cover subject on tracking of policies and actions in the NDC, planning mitigation actions, GHG inventories, and monitoring and reporting of support needed and received.

This study proposes an updated institutional arrangement for the national MRV system (Figure 8). This suggests replacing institutions that are no longer active, revitalizing the role of institutions that currently have little involvement, and adding other institutions with a more active role, such as the National Institute of Statistics (INE) and the Ministry of Economy and Finance (MEF). It proposes introducing a climate change reporting instrument (law or decree-law) to ensure that data related to climate change is shared between institutions allowing the MITA to fulfill its mandate.

Most of the needed data for GHG emission estimation are from charcoal producers (Table 5). Currently, only the total area per licensed producer and the number of charcoal bags produced per operator is recorded. To estimate charcoal emissions accurately, there are several data for gathering (Table 5). There is an urgent need for developing equations that predict the amount or volume of extracted forest resources for charcoal production $\left(\mathrm{m}^{3}\right.$, bags) per type of technology and quantity of biomass per tree component (stem, branches, leaves) used for charcoal production to support impact assessments.

All charcoal value chain players have a role in data provision, monitoring, and reporting. Therefore, charcoal transporters, which are part of the value chain, would need to report to SDAE on the quantity of charcoal bags transported, the amount of fuel and lubricants consumed, markets supplied, or distance traveled. The introduction of a simple form for different actors stating the critical data needs would be crucial to allow database development and operationalization of the existing institutional arrangement. The frequency of reporting is on a monthly base to charcoal producers, transporters, and traders. 


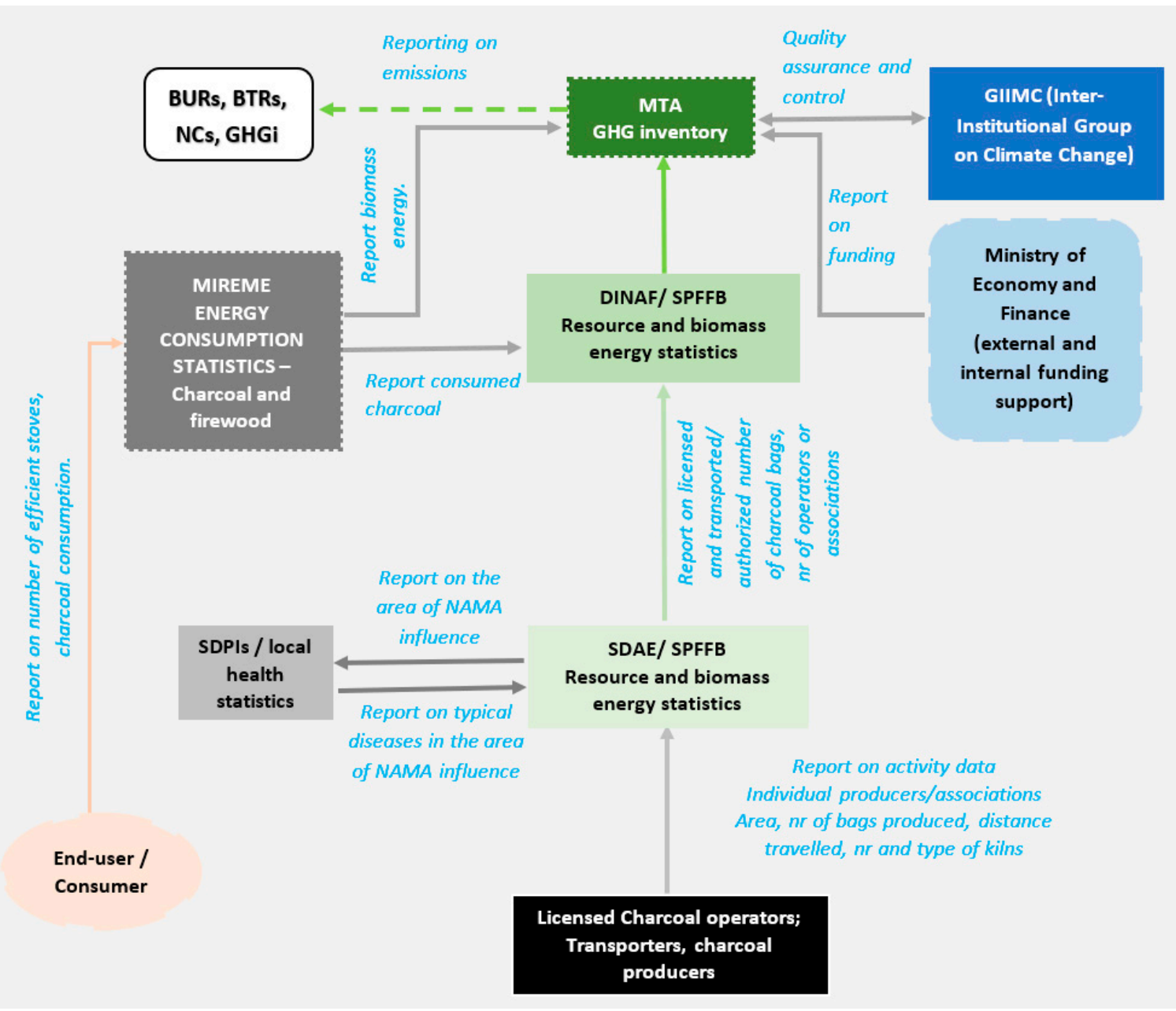

Figure 8. Mapping of key stakeholders and roles for the reporting, monitoring, and evaluation of the Charcoal NAMA toward an enhanced transparency framework. MTA: Ministry of Land and Environment; MIREME: Ministry of Mineral Resources; DINAF: National Directorate of Forestry; SPFFB: Provincial Service of Forest and Wildlife; SDAE: District Service for Economic Activities; SDPI: District Service of Planning and Infrastructure. 
Table 5. Proposed structure for gathering and reporting the needed data to enable tracking of implementation of the NAMA, contributing to the Nationally Determined Contributions' (NDC) transparency overall.

\begin{tabular}{|c|c|c|c|c|c|}
\hline Parameter & Key Performance Indicator & $\begin{array}{c}\text { Entity } \\
\text { Responsible for } \\
\text { Measuring }\end{array}$ & $\begin{array}{c}\text { Entity } \\
\text { Responsible for Reporting }\end{array}$ & $\begin{array}{c}\text { Entity } \\
\text { Responsible for Data Sharing }\end{array}$ & $\begin{array}{l}\text { Monitoring } \\
\text { Frequency }\end{array}$ \\
\hline Forest area & $\begin{array}{l}\text { The forest loss due to charcoal } \\
\text { production. }\end{array}$ & \multirow{8}{*}{$\begin{array}{l}\text { Charcoal operators or } \\
\text { associations (producers) }\end{array}$} & \multirow{11}{*}{$\begin{array}{c}\text { District Service for } \\
\text { Economic Activities (SDAE), } \\
\text { Provincial Service of Forest } \\
\text { and Wildlife (SPFFB) }\end{array}$} & \multirow{11}{*}{$\begin{array}{l}\text { National Directorate of Forestry } \\
\text { (DINAF) }\end{array}$} & \multirow{7}{*}{ Quarterly } \\
\hline Resource use & $\begin{array}{l}\text { The number of trees per species } \\
\text { used for charcoal production. }\end{array}$ & & & & \\
\hline Stand tree & $\begin{array}{l}\text { A ton of biomass per tree } \\
\text { component (stem, branches, } \\
\text { leaves) used for charcoal } \\
\text { production per tree. }\end{array}$ & & & & \\
\hline Coppice & $\begin{array}{l}\text { A number of trees coppicing in } \\
\text { the area (natural regeneration or } \\
\text { regrowth). }\end{array}$ & & & & \\
\hline Forest management & $\begin{array}{l}\text { Hectares under sustainable forest } \\
\text { management. }\end{array}$ & & & & \\
\hline \multirow{2}{*}{$\begin{array}{l}\text { Kilns installed or used for } \\
\text { charcoal licensed }\end{array}$} & Number and type of kilns. & & & & \\
\hline & The efficiency rate of each kiln. & & & & \\
\hline Charcoal produced & $\begin{array}{l}\text { A number of charcoal bags } \\
\text { produced/ licensed per kiln type. }\end{array}$ & & & & \multirow{4}{*}{ Annually } \\
\hline Charcoal Transported & $\begin{array}{l}\text { The amount of charcoal bags } \\
\text { transported per trip. }\end{array}$ & \multirow{3}{*}{ Charcoal transporters } & & & \\
\hline $\begin{array}{l}\text { Distance traveled from to } \\
\text { charcoal production area/ } \\
\text { markets to end-users }\end{array}$ & $\begin{array}{l}\text { The number of trips and } \\
\text { kilometers traveled for charcoal } \\
\text { transport. }\end{array}$ & & & & \\
\hline $\begin{array}{l}\text { Fuel and lubricants } \\
\text { consumption }\end{array}$ & Amount of fuel and lubricants. & & & & \\
\hline
\end{tabular}




\section{Conclusions}

This study aimed to evaluate the NAMA's options concerning their carbon emission reduction potential in Mozambique, applying the ICAT guidance on Sustainable Development to an enhanced transparency framework at a subnational and national scale in Mozambique. The ICAT guidance performed well as a tool for assessing the impact ex-ante of charcoal NAMA implementation in Mozambique and provided additional information that is useful to communicate the potential effects of the support that might be channeled to implement the charcoal NAMA. According to a cumulative scenario, there is a potential to reduce emissions at the subnational and the national scale up to 2030 . If implemented successfully at the national level, the NAMA can contribute towards the achievement of the Mozambique NDC targets and SDGs.

The NAMA of Mozambique has never been implemented since it was designed in 2014, and its implementation is subject to financial, technological, and capacity-building support. Considering Mozambique's socio-economic context, high poverty level, limited access to modern energy, easy access, and at the free cost of biomass, charcoal will continue to dominate Mozambique's total energy, so it is urgent to implement the NAMA. As means of implementation may be the limiting factor for most developing countries, the NAMA is seen as a means to mobilize the financial resources needed to implement national priorities for sustainable development and promote low emission practices by developing countries.

The generation of new activity data is seen as the most challenging process as most of the existing MRV systems are established to accommodate older policies' MRV needs and not necessarily data collection or measurements for new activities. Improvement in data gathering and information flows to appropriate levels will be needed for a continuous and robust assessment of the NAMA impacts. So, there will be a need for capacity building and reporting guidance to charcoal producers and district-level staff training in methodologies and procedures for data, reporting, and monitoring.

\section{Limitations}

The scenario result has the potential for bias from data, mainly at the national level. This study combined primary data collected in the targeted districts and secondary data gathered from national institutions. However, the lack of a database with relevant, consistent, and standardized information over time and different locations affected the quality of data, hence the accuracy of the scenario results. These results, therefore, need to be interpreted with caution, mainly those results scaled up to the national level. We collected field data in the targeted pilot districts. However, this data has some limitations on responses as most of the interviewed (transporters, producers, and consumers) did not provide accurate information because of a lack of frequent recording. The data limitation issue was the main reason for excluding most the impact categories from the quantitative assessment.

Supplementary Materials: The following are available online at http://www.mdpi.com/2071-1050/12/24/10390/s1, The further details on fieldwork, impact assessment methodology, equations used to emission estimation, and impact characterization description supporting this article have been uploaded as part of the electronic supplementary material.

Author Contributions: Conceptualization, S.N.L. and R.M.; original draft preparation, formal analysis and revised the manuscript, S.N.L.; funding acquisition, R.M.; writing-review and editing, S.N.L., R.M., and A.S.; investigation and validation, A.M. All authors have read and agreed to the manuscript's published version.

Funding: This work was funded by the Initiative for Climate Action Transparency-ICAT with support from the World Resources Institute, UNEP DTU Partnership.

Acknowledgments: The authors acknowledge the contribution of Eng. Paula Panguene, and dra. Telma Manjate to the administrative support and for organizing the national workshops. The coauthors wish to thank Eng. Osório Nhiuane and Eng. Felício Guelume for their field research assistance. We also thank Federico Canu for the study conceptualization and for the manuscript revision; and Margaret B. Holland for language revision. To the two anonymous reviewers for their valuable suggestions and comments, thank you.

Conflicts of Interest: The authors declare no conflict of interest. 


\section{References}

1. UNFCCC. Paris Agreement. 2015. Available online: http:Unfccc.int/files/meetings/paris_nov_2015/ application/pdf/paris_agreement_english_.pdf (accessed on 19 August 2020).

2. Falcão, M.P. Charcoal Production and Use in Mozambique, Malawi, Tanzania, and Zambia: Historical Overview, Present Situation, and Outlook; UEM: Mpauto, Mozambique, 2008.

3. INE. IV Recenseamento Geral da População e Habitação 2017; Resultados Definitivos: Mpauto, Mozambique, 2019.

4. Falcão, M.; Sumaila, R.; Grundy, I.; Geldenhuys, C. The impact of policy on resource use in Mozambique: A case study of Savane. Silva Lusit. 2007, 15, 89-102.

5. Brouwer, R.; Falcão, M.P. Wood fuel consumption in Maputo, Mozambique. Biomass Bioenergy 2014, 27, $233-245$. [CrossRef]

6. Sedano, F.; Silva, J.A.; Machoco, R.; Meque, C.H.; Sitoe, A.; Ribeiro, N.; Anderson, K.; Ombe, Z.A.; Baule, S.H.; Tucker, C.J. The impact of charcoal production on forest degradation: A case study in Tete, Mozambique. Environ. Res. Lett. 2016, 11. [CrossRef] [PubMed]

7. Sedano, F.; Lisboa, S.N.; Duncanson, L.; Ribeiro, N.; Sitoe, A.; Sahajpal, R.; Hurtt, G.; Tucker, C.J. Monitoring forest degradation from charcoal production with historical Landsat imagery. A case study in southern Mozambique. Environ. Res. Lett. 2020, 15. [CrossRef]

8. Baumert, S.; Luz, A.C.; Fisher, J.; Vollmer, F.; Ryan, C.M.; Patenaude, G.; Zorrilla-Miras, P.; Artur, L.; Nhantumbo, I.; Macqueen, D. Energy for Sustainable Development Charcoal supply chains from Mabalane to Maputo: Who benefits? Energy Sustain. Dev. 2016, 33, 129-138. [CrossRef]

9. Zorrilla-Miras, P.; Mahamane, M.; Metzger, M.J.; Baumert, S.; Vollmer, F.; Luz, A.C.; Woollen, E.; Sitoe, A.A.; Patenaude, G.; Nhantumbo, I.; et al. Environmental Conservation and Social Benefits of Charcoal Production in Mozambique. Ecol. Econ. 2018, 144, 100-111. [CrossRef]

10. Government of Mozambique. Mozambique Biomass Strategy; Ministry of Energy: Maputo, Mozambique, 2012.

11. De Koning, P.C.; Atanassov, B.; Heidemann, F.; Jorritsma, M. Sustainable Charcoal Value Chain Mozambique: Feasibility Study on climate financing for a Sustainable Charcoal Production Chain. Energy Eng. Solut. 2014. Available online: https://www.google.com.hk/url?sa=t\&rct=j\&q=\&esrc=s\&source=web\&cd= \&ved=2ahUKEwiCreXDitbsAhWSGKYKHeliDZYQFjAAegQIAxAC\&url=http\%3A\%2F\%2Fgreenlightafrica.com\%2Fassets\%2Fees_international_(2014)_feasibility_study_charcoal_mozambique_final_with_ translation.pdf\&usg=AOvVaw1Ps7hsetZh76GjwvErAgwi (accessed on 28 May 2020).

12. United Nations General Assembly. Transforming Our World: The 2030 Agenda for Sustainable Development; Division for Sustainable Development Goals: New York, NY, USA, 2015. Available online: https:// sustainabledevelopment.un.org/post2015/transformingourworld/publication (accessed on 19 August 2020).

13. Sedano, F.; Lisboa, S.N.; Duncanson, L.; Ribeiro, N.; Sitoe, A.; Sahajpal, R.; Hurtt, G.; Tucker, C.J. Monitoring intra and inter annual dynamics of forest degradation from charcoal production in Southern Africa with Sentinel-2 imagery. Int. J. Appl. Earth Obs. Geoinf. 2020, 92, 102184. [CrossRef]

14. ICAT (Initiative for Climate Action Transparency). Sustainable Development Methodology: Assessing the Environmental, Social and Economic Impacts of Policies and Actions; Copenhagen: UNEP DTU Partnership; Rich, D., Song, R., Olsen, K.H., Eds.; World Resources Institute: Washington, DC, USA, 2020. Available online: https://climateactiontransparency.org/icat-toolbox/sustainable-development (accessed on 10 May 2020).

15. Electricidade de Mocambique, E.P. EDM Strategy 2018-2028; Electricidade de Mocambique: Maputo, Mozambique, 2018.

16. Government of Mozambique. Estrategia de Desenvolvimento de Energias novas e renovaveis (EDENR) 2011-2025; Ministerio de Energia: Maputo, Mozambique, 2011.

17. DINAF. Relatórios de Balanco Annual de Terras, Florestas e Fauna Bravia-2017; DINAF: Maputo, Mozambique, 2017.

18. Government of Mozambique. Plano Estrategico de Educacao 2012-2016; MINED: Maputo, Mozambique, 2012.

19. Pereira, C.; Brouwer, R.; Monjane, M.; Falcão, M.P. Final report for Mozambique. In Charcoal Potential in Southern Africa; Ellegård, A., Ed.; Stockholm Environment Institute: Stockholm, Sweden, 2001.

20. Alberto, M.M. A Contribution of the Forestry and Wildlife Sector to the Country's Economy; National Directorate of Forestry and Wildlife: Maputo, Mozambique, 2006. 
21. Nhancale, B.A.; Mananze, S.E.; Dista, N.F.; Nhantumbo, I.; Macqueen, D.J. Small and Medium Forest Enterprises in Mozambique; IIED Small and Medium Forest Enterprise Series No. 25; Centro Terra Viva and International Institute for Environment and Development: London, UK, 2009.

22. Government of Mozambique. Mozambique's Forest Reference Emission Level for Reducing Emissions from Deforestation in Natural Forests; Government of Mozambique: Maputo, Mozambique, 2018.

23. UNFCCC CDM AMS-III.BG. Emission Reduction through Sustainable Charcoal Production and Consumption. Available online: https://cdm.unfccc.int/methodologies/DB/MVOAXD3LGD4ZJEKEERCT39ZLJ3JZA0 (accessed on 15 April 2019).

24. UNFCCC CDM AMS-III-K. Avoidance of Methane Release from Charcoal Production. Available online: https://cdm.unfccc.int/methodologies/DB/5RNUZSHHSABLSU97RQSDFB2D433ECB/view.html (accessed on 15 April 2019).

25. UNFCCC CDM ACM0021. Reduction of Emissions from Charcoal Production by Improved Kiln Design and/or Abatement of Methane EB67_repan08_ACM0021_NM0341. Available online: https://cdm.unfccc.int/ methodologies/DB/AA1T5PNLA4SMCJA2OQK9XRTC08BA6J (accessed on 15 April 2019).

26. IPCC. 2006 IPCC Guidelines for National Greenhouse Gas Inventories; Prepared by the National Greenhouse Gas Inventories, Programme; Eggleston, H.S., Buendia, L., Miwa, K., Ngara, T., Tanabe, K., Eds.; Institute for Global Environmental Strategies: Kanagawa, Japan, 2006.

27. Mate, R.; Johansson, T.; Sitoe, A. Biomass Equations for Tropical Forest Tree Species in Mozambique. Forests 2014, 5, 535-556. [CrossRef]

28. Mate, R.; Johansson, T.; Sitoe, A. Stem Volume Equations for Valuable Timber Species in Mozambique. J. Sustain. For. 2015, 34, 787-806. [CrossRef]

29. Kalaba, F.K.; Quinn, C.H.; Dougill, A.J.; Vinya, R. Floristic composition, species diversity and carbon storage in charcoal and agriculture fallows and management implications in Miombo woodlands of Zambia. For. Ecol. Manag. 2013, 304, 99-109. [CrossRef]

30. FAO. The Charcoal Transition: Greening the Charcoal Value Chain to Mitigate Climate Change and Improve Local Livelihoods; Food and Agriculture Organization of the United Nations: Rome, Italy, 2017.

31. Brown, S.; Sathaye, J.A.; Cannell, M.; Kauppi, P. Management actions: Mitigation of carbon emissions to the atmosphere by forest management. Commonw. For. Rev. 1996, 75, 80-91.

32. Mwampamba, T.H. Has the woodfuel crisis returned? Urban charcoal consumption in Tanzania and its implications to present and future forest availability. Energy Policy 2007, 35, 4221-4234. [CrossRef]

33. Chidumayo, E.N.; Gumbo, D.J. The environmental impacts of charcoal production in tropical ecosystems of the world: A synthesis. Energy Sustain. Dev. 2013, 17, 86-94. [CrossRef]

34. Government of Mozambique. Plano de operacionalização da NDC; Versão Resumo; MITADER: Maputo, Mozambique, 2018.

35. Cucchiella, F.; D'Adamo, I.; Gastaldi, M.; Koh, S.C.L.; Santibanez-Gonzalez, E.D.R. Assessment of GHG emission in Europe: Future estimates and policy implications. Environ. Eng. Manag. J. 2020, 19, 131-142.

36. Batidzirai, B.; Faaij, A.P.; Smeets, E. Biomass and bioenergy supply from Mozambique. Energy Sustain. Dev. 2006, 10, 54-81. [CrossRef]

37. Mate, R. Potentials and Wood Fuel Quality of Logging Residues from Indigenous and Planted Forests in Mozambique. Ph.D. Thesis, Swedish University of Agricultural Sciences, Uppsala, Sweden, 2016.

Publisher's Note: MDPI stays neutral with regard to jurisdictional claims in published maps and institutional affiliations.

(C) 2020 by the authors. Licensee MDPI, Basel, Switzerland. This article is an open access article distributed under the terms and conditions of the Creative Commons Attribution (CC BY) license (http://creativecommons.org/licenses/by/4.0/). 